ANALISIS IMPLEMENTASI AUGMENTED REALITY (AR) BERBASIS MARKER-BASED TRACKING SEBAGAI MEDIA PEMBELAJARAN HIDROPONIK

PENULISAN ILMIAH

Oleh:

IRVAN DWI SAPUTRA

16411018

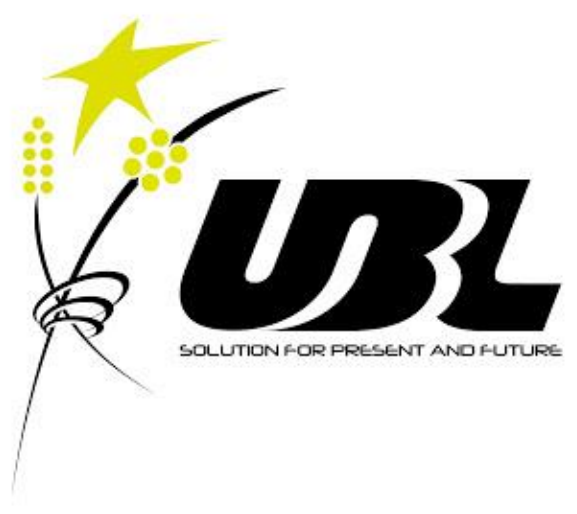

PROGRAM STUDI SISTEM INFORMASI

FAKULTAS ILMU KOMPUTER

UNIVERSITAS BANDAR LAMPUNG

2019 


\title{
ANALISIS IMPLEMENTASI AUGMENTED REALITY (AR) BERBASIS MARKER-BASED TRACKING SEBAGAI MEDIA PEMBELAJARAN HIDROPONIK
}

\author{
PENULISAN ILMIAH \\ Diajukan Sebagai Salah Satu Syarat untuk Mengambil Tugas Akhir Kesarjanaan \\ Strata-1 (S1) pada Program Studi Sistem Informasi Fakultas Ilmu Komputer \\ Universitas Bandar Lampung
}

Oleh:

IRVAN DWI SAPUTRA

16411018

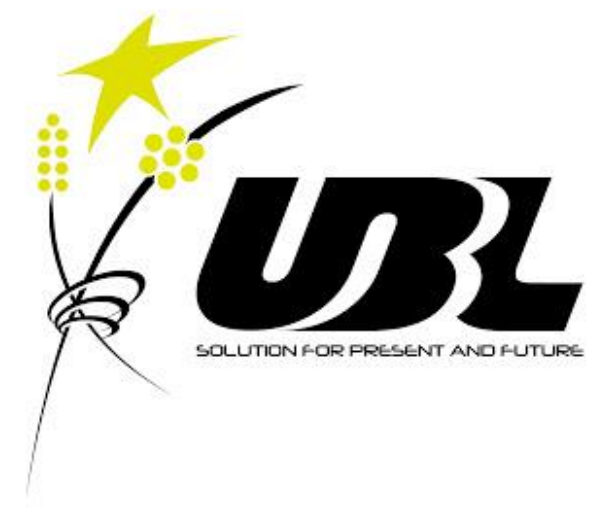

PROGRAM STUDI SISTEM INFORMASI

FAKULTAS ILMU KOMPUTER

UNIVERSITAS BANDAR LAMPUNG

2019 


\section{LEMBAR PENGESAHAN}

\section{Judul Penulisan IImiah $\quad$ ANALISIS IMPLEMENTASI AUGMENTED REALITY (AR) BERBASIS MARKER BASED TRACKING SEBAGAI MEDIA PEMBELAJARAN HIDROPONIK}

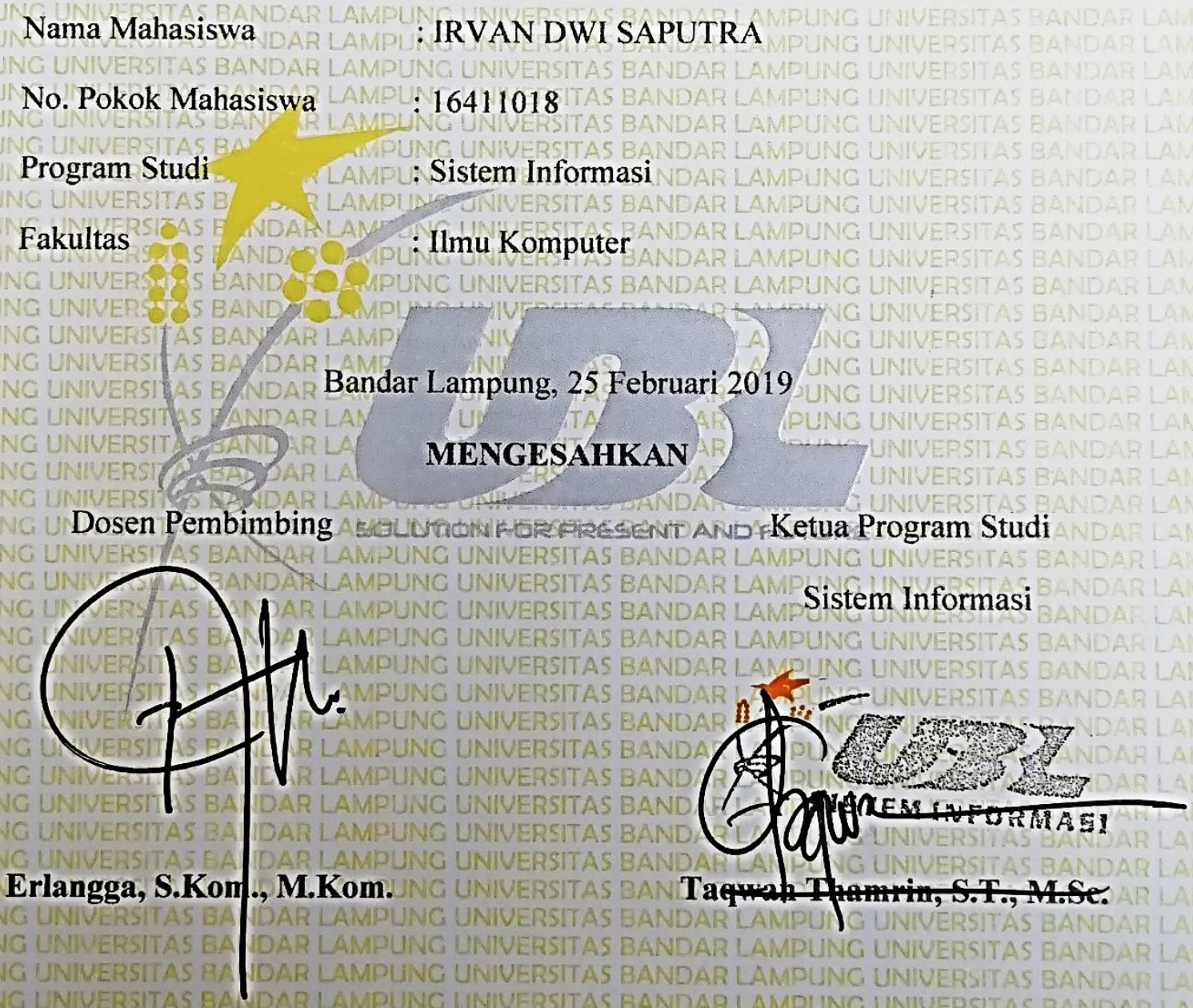









\section{ABSTRAK \\ ANALISIS IMPLEMENTASI AUGMENTED REALITY (AR) BERBASIS \\ MARKER-BASED TRACKING SEBAGAI MEDIA PEMBELAJARAN HIDROPONIK}

Oleh:

Irvan Dwi Saputra

16411018

Teknologi berkembang begitu pesat dalam proses pembelajaran, pada mulanya proses pembelajaran yang dilakukan hanya dengan menggunakan buku dan berkembang menggunakan media Augmented Reality. Augmented Reality merupakan teknologi yang menggabungkan benda maya dua atau tiga dimensi kedalam lingkungan nyata. AR memiliki banyak manfaat pada berbagai bidang seperti hiburan dan ilmu kedokteran. Adapun tujuan dari penelitian ini adalah membuat aplikasi media pembelajaran hidroponik dengan menggunakan kertas sebagai tempat marker.Pengguna dapat mengetahui informasi dengan mengarahkan kamera pada aplikasi ke kertas yang sudah di beri marker dan aplikasi akan menampilkan informasi berupa teks dan animasi yang peneliti maksud adalah berupa proses dari penanaman hidroponik, dengan begitu akan mudah dipahami pengguna dalam mempelajari hidroponik.

Kata Kunci: AR, Augmented Reality, Marker-Based Tracking, Media Pembelajaran, Hidroponik 


\title{
ABSTRACT \\ ANALYSIS OF AUGMENTED REALITY (AR) IMPLEMENTATION BASED ON MARKER-BASED TRACKING AS A HYDRAULIC LEARNING MEDIA
}

\author{
by: \\ Irvan Dwi Saputra \\ 16411018
}

Technology develops so rapidly in the learning process, at first the learning process is carried out only by using books and developing using Augmented Reality media. Augmented Reality is a technology that combines two or three-dimensional virtual objects into the real environment. AR has many benefits in various fields such as entertainment and medical science. The purpose of this study is to make the application of hydroponic learning media using paper as a marker. Users can find out information by directing the camera on the application to the paper that has been given a marker and the application will display information in the form of text and animation that the researchers intend is in the form of a hydroponic planting process, so that users will easily understand hydroponics.

Keywords: AR, Augmented Reality, Marker-Based Tracking, Learning Media, Hydroponic 


\section{KATA PENGANTAR}

Puji dan syukur penulis panjatkan ke hadirat Allah SWT, yang telah memberikan izin dan kekuatan, sehingga penulis dapat menyelesaikan Penulisan Ilmiah ini dengan judul “Analisis Implementasi Augmented Reality (AR) Berbasis Marker-Based Tracking Sebagai Media Pembelajaran Hidroponik” tepat pada waktunya.Penulian Ilmiah ini dibuat sebagai salah satu syarat untuk dapat mengambil Tugas Akhir atau Skripsi.

Penulis menyadari bahwa dalam pembuatan Penulisan Ilmiah ini tidak terlepas dari bantuan dan bimbingan dari semua pihak sehingga Penulisan Ilmiah dapat diselesaikan dengan baik. Dengan ini penulis mengucapkan terima kasih kepada :

1. Ibu Dra. Hj. Sri Hayati Barusman, selaku Ketua Pembina Yayasan Administrasi Universitas Bandar Lampung.

2. Bapak Dr. Ir. H. Yusuf Sulfarano Barusman, MBA, selaku Rektor Universitas Bandar Lampung.

3. Bapak Dr. Andala Rama Putra Barusman, SE., MA.Ec., selaku Direktur Eksekutif Yayasan Universitas Bandar Lampung.

4. Bapak Ahmad Cucus, S.Kom., M.Kom selaku Dekan Fakultas Ilmu Komputer.

5. Bapak Taqwan, S.T., M.Sc selaku Ketua Program Studi Sistem Informasi.

6. Bapak Erlangga Zildjian, S.Kom., M.Kom. selaku pembimbing akademik sekaligus sebagai pembimbing dalam Penulisan Ilmiah ini yang telah membimbing, memberikan pengarahan dalam menyelesaikan penulisan ilmiah ini.

7. Seluruh dosen dan staff pengajar Fakultas Ilmu Komputer Universitas Bandar Lampung.

8. Orang tua dan adik tercinta di rumah yang selalu mendukung dan memberi semangat.

9. Teman-teman angkatan 2016 Sistem Informasi Fakultas Ilmu Komputer Universitas Bandar Lampung. 
10. Teman-teman pengurus Himpunan Mahasiswa Program Studi Sistem Informasi Fakultas Ilmu Komputer Universitas Bandar Lampung (HMSI FIK UBL).

11. Seluruh pihak yang telah membantu penulis dalam menyelesaikan Penulisan Ilmiah ini.

Penulis menyadari bahwa hasil Penulisan Ilmiah ini masih banyak kekurangan dan kelemahannya, baik dalam isi maupun sistematikanya. Oleh sebab itu, penulis sangat mengharapkan kritik dan saran untuk menyempurnakan penulisan ini. semoga hasil Penulisan Ilmiah ini dapat memberikan manfaat, khususnya bagi penulis dan umumnya bagi pembaca.

Bandar Lampung, 21 Februari 2019

Irvan Dwi Saputra 


\section{DAFTAR ISI}

\section{COVER}

LEMBAR PENGESAHAN ..................................................................... iii

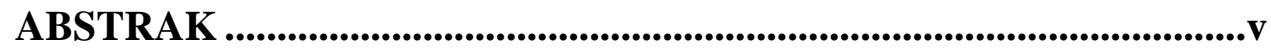

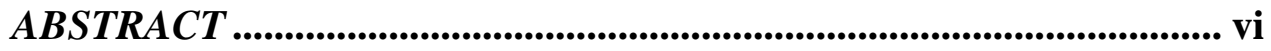

KATA PENGANTAR.................................................................................. vii

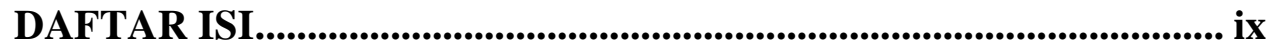

DAFTAR GAMBAR ......................................................................

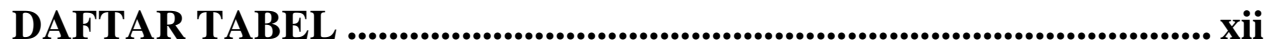

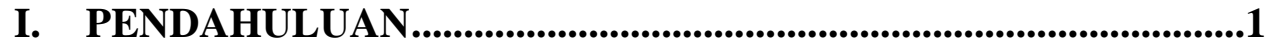

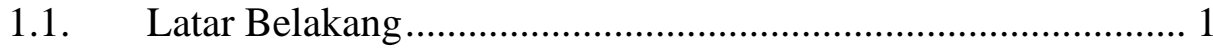

1.2. Identifikasi Masalah............................................................ 2

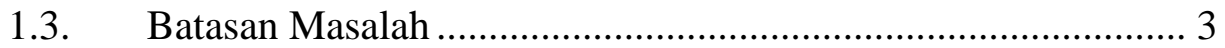

1.4. Rumusan Masalah......................................................................... 3

1.5. Kerangka Pemikiran ............................................................ 3

1.6. Sistematika Penulisan ............................................................... 4

II. LANDASAN TEORI......................................................................6

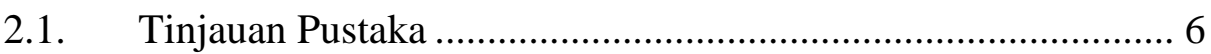

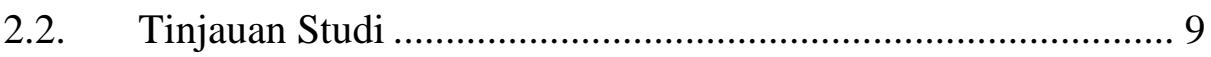

III. TUJUAN DAN MANFAAT PENELITIAN .................................18

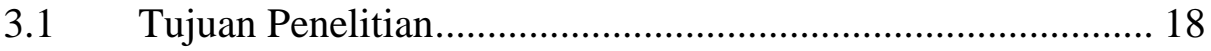

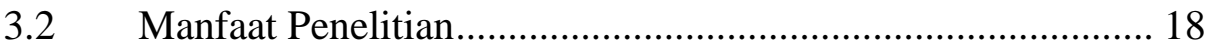

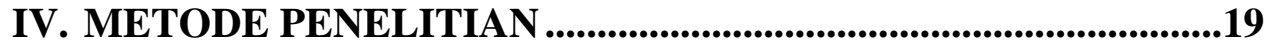


4.1 Metode Pengumpulan Data .................................................. 19

4.2 Analisis Kebutuhan ........................................................... 21

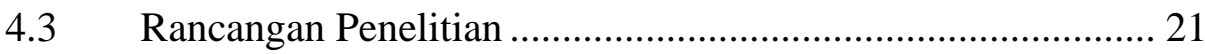

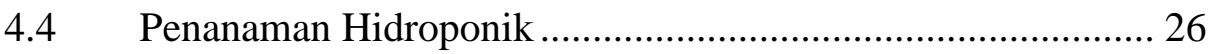

V. HASIL ANALISA DAN PEMBAHASAN ....................................34

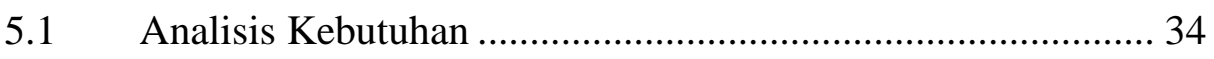

5.2 Augmented Reality Sebagai Media Pembelajaran Hidroponik35

5.3 Analisis Sistem dan Pembahasan .......................................... 36

VI. RENCANA PENELITIAN BERIKUTNYA_.............................53

VII. KESIMPULAN DAN SARAN ............................................54

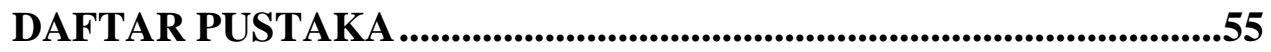

LAMPIRAN

Lampiran 1. Jadwal Kegiatan Bimbingan Penulisan Ilmiah................ 59

Lampiran 2. Perbaikan Pasca Sidang Penulisan Ilmiah..................... 61

Lampiran 3. Berita Acara Cetak Soft Cover......................................... 62 


\section{DAFTAR GAMBAR}

Gambar 1. 1. Kerangka Pemikiran..................................................................... 3

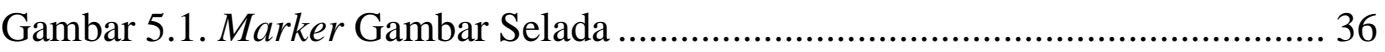

Gambar 5. 2. Ilustrasi dari Titik Kordinat......................................................... 37

Gambar 5. 3. Alur Augmented Reality Marker-Based Tracking ......................... 38

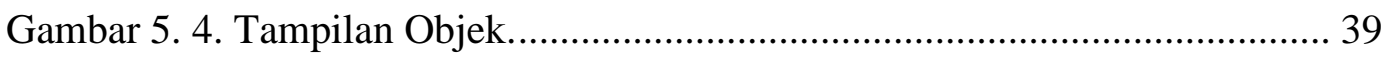

Gambar 5. 5. Tampilan Objek Virtual di Smartphone ....................................... 40

Gambar 5. 6. Tampilan dari Uji Pencahayaan Diatas 200 Lux............................ 41

Gambar 5. 7. Tampilan dari Uji Pencahayaan 7 - 200 Lux ............................... 42

Gambar 5. 8. Tampilan dari Uji Pencahayaan antara 2 Lux - 6 Lux................... 43

Gambar 5. 9. Tampilan dari Uji Pencahayaan Dibawah 1 Lux .......................... 43

Gambar 5. 10. Tampilan Hasil Deteksi Marker Dari Jarak 10cm........................ 44

Gambar 5. 11.Tampilan Hasil Deteksi Marker dari Jarak $30 \mathrm{~cm}$........................ 45

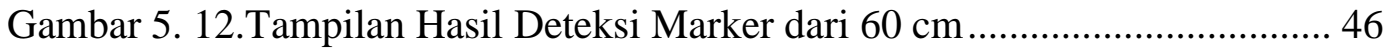

Gambar 5. 13.Tampilan Hasil Deteksi Marker dari $120 \mathrm{~cm}$.............................. 46

Gambar 5. 14. Uji Marker Dicoret (kiri) dan Marker Tetap Terdeteksi (kanan) . 47

Gambar 5. 15. Uji Marker Dirobek (kiri) dan Marker Tidak Terdeteksi (kanan) 48

Gambar 5. 16. Uji Marker Diremuk (kiri) dan Marker Tidak Terdeteksi (kanan) 49

Gambar 5. 17. Uji Marker dengan Smartphone Huawei P9 Lite ......................... 50

Gambar 5. 18.Uji Marker dengan Smartphone Honor 9 Lite .............................. 50

Gambar 5. 19. Uji Marker dengan Smartphone Xiomi Redmi Note 4X ............. 51

Gambar 5. 20. Uji Marker dengan Smartphone Xiomi 5A ................................ 52

Gambar 6. 1. Kerangka Pemikiran Penelitian Selanjutnya..................................53 


\section{DAFTAR TABEL}

Tabel 4. 1. Hasil Observasi............................................................................ 20

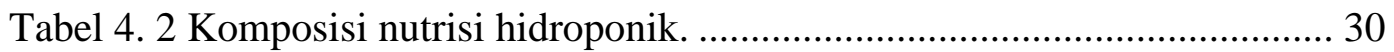

Tabel 5. 1. Kebutuhan Perangkat Lunak (Software)........................................... 34

Tabel 5. 2. Kebutuhan Perangkat Keras (Hardware) ........................................... 35 


\section{PENDAHULUAN}

\subsection{Latar Belakang}

Pembelajaran merupakan bantuan yang diberikan pendidik agar dapat terjadi proses pemerolehan ilmu dan pengetahuan, penguasaan kemahiran dan tabiat, serta pembentukan sikap dan kepercayaan pada peserta didik. Dengan Perkembangan dunia teknologi informasi yang saat ini sangat cepat karena didorong oleh kebutuhan data dan informasi. Perkembangan teknologi informasi yang begitu pesat ini memungkinkan diterapkannya cara-cara yang lebih efisien untuk produksi, distribusi, dan konsumsi barang dan jasa.

Banyak sekali dampak positif yang bisa kita rasakan dari peran teknologi. Teknologi smartphone tidak bisa dipandang sebelah mata karena keberadaan dan kemajuannya. Ada banyak kemajuan yang mendorong berfungsinya pendidikan dengan baik. Teknologi dapat memainkan peran penting dalam motivasi, keterlibatan, dan inspirasi. (Erlangga \& Dharmawan, 2017). Pertumbuhan End User Computing (EUC) merupakan salah satu fenomena penting dalam beberapa tahun terakhir. Menurut pengamatan dari perusahaan data internasional, dari 5 profesional dan administratif menggunakan komputer pribadi untuk mendukung pekerjaan dan aktivitas pribadi (Ilias, dikutip dalam Nursyanti \& Erlangga, 2013). Kita sebagai individu harus pintar dalam hal bagaimana memanfaatkannya. Tapi, bukan hanya dalam pemanfaatannya saja, kita harus bisa turut berperan aktif dalam mengembangkan teknologi tersebut, supaya kita dapat belajar dan dapat memberikan manfaat kepada individu lain.

Augmented Reality (AR) merupakan suatu istilah yang berkaitan dengan lingkungan yang menggabungkan dunia nyata dengan dunia virtual yang diciptakan oleh komputer menjadikan batas antara keduanya menjadi sangat tipis. Sistem ini lebih mengarah terhadap lingkungan secara nyata atau real, Augmanted realitiy lebih mengutamakan sistem ini (Brian, 2012). AR memiliki banyak potensi di dalam industri dan penelitian akademis. Augmented Reality merupakan sebuah trend teknologi saat ini, yang memiliki banyak sekali manfaat dalam kehidupan kita salah satunya bisa digunakan media pembelajaran hidroponik. 
Hidroponik adalah istilah yang digunakan untuk menjelaskan beberapa cara bercocok tanam tanpa menggunakan tanah sebagai tempat menanam tanaman. (Lingga, 1984). Hidroponik menjadi sebuah alternatif bagi masyarakat yang ingin berkebun namun tidak memiliki cukup tempat untuk bercocok tanam. Hidroponik adalah lahan budidaya pertanian tanpa menggunakan media tanah, sehingga hidroponik merupakan aktivitas pertanian yang dijalankan dengan menggunakan air sebagai medium untuk menggantikan tanah. Namun bercocok tanam dengan cara hidroponik ini perlu penanganan, perawatan dan pemantauan yang lebih dibandingkan dengan bercocok tanam konvensional dengan media tanah. Sehingga pemilik perlu untuk memberikan perhatian lebih kepada tanamannya (Ibadarrohman, Nur , \& Anacotiana, 2018).

Salah satunya pemanfaatan teknologi Augmented Reality sebagai media pembelajaran hidroponik akan sangat membantu dalam hal pengenalan proses dari penanaman hidroponik. Minimnya pemanfaatan Augmented Reality pada bidang tersebut membuat peneliti tertarik untuk membangun sebuah sistem berbasis Android menggunakan konsep dari Augmented Reality dimana pengguna dapat mengetahui informasi mengenai hidroponik dengan media marker berupa kertas. Untuk mengetahui apakah konsep Augmented Reality dapat diterapkan sebagai media pembelajaran hidroponik tersebut, dengan latar belakang masalah tersebut, maka dalam penulisan ilmiah peneliti mengambil judul "Analisis Implementasi Augmented Reality (AR) Berbasis Marker-Based Tracking Sebagai Media Pembelajaran Hidroponik".

\subsection{Identifikasi Masalah}

Berdasarkan latar belakang diatas identifikasi masalah yang muncul dalam penelitian ini yaitu dalam bercocok tanam hidroponik perlu penanganan khusus maka perlu adanya media pembelajaran hidroponik yang mudah dipahami dan belum diketahui apakah konsep AR (Augmented Reality) bisa diterapkan untuk media pembelajaran hidroponik. 


\subsection{Batasan Masalah}

Melihat latar belakang dan identifikasi masalah diatas penulis membatasi masalah yang akan diteliti hanya menganalisis konsep AR (Augmented Reality) untuk pembelajaran hidroponik.

\subsection{Rumusan Masalah}

Berdasarkan latar belakang yang telah dibahas sebelumnya, maka dapat diperoleh rumusan masalah yang akan dibahas dalam penelitian ini adalah "Bagaimana analisis implementasi Augmented Reality(AR) Berbasis MarkerBased Tracking sebagai media pembelajaran Hidroponik? ".

\subsection{Kerangka Pemikiran}

\section{PENGUMPULAN DATA}

- Mengumpulkan data yang diperlukan untuk menunjang penelitian.

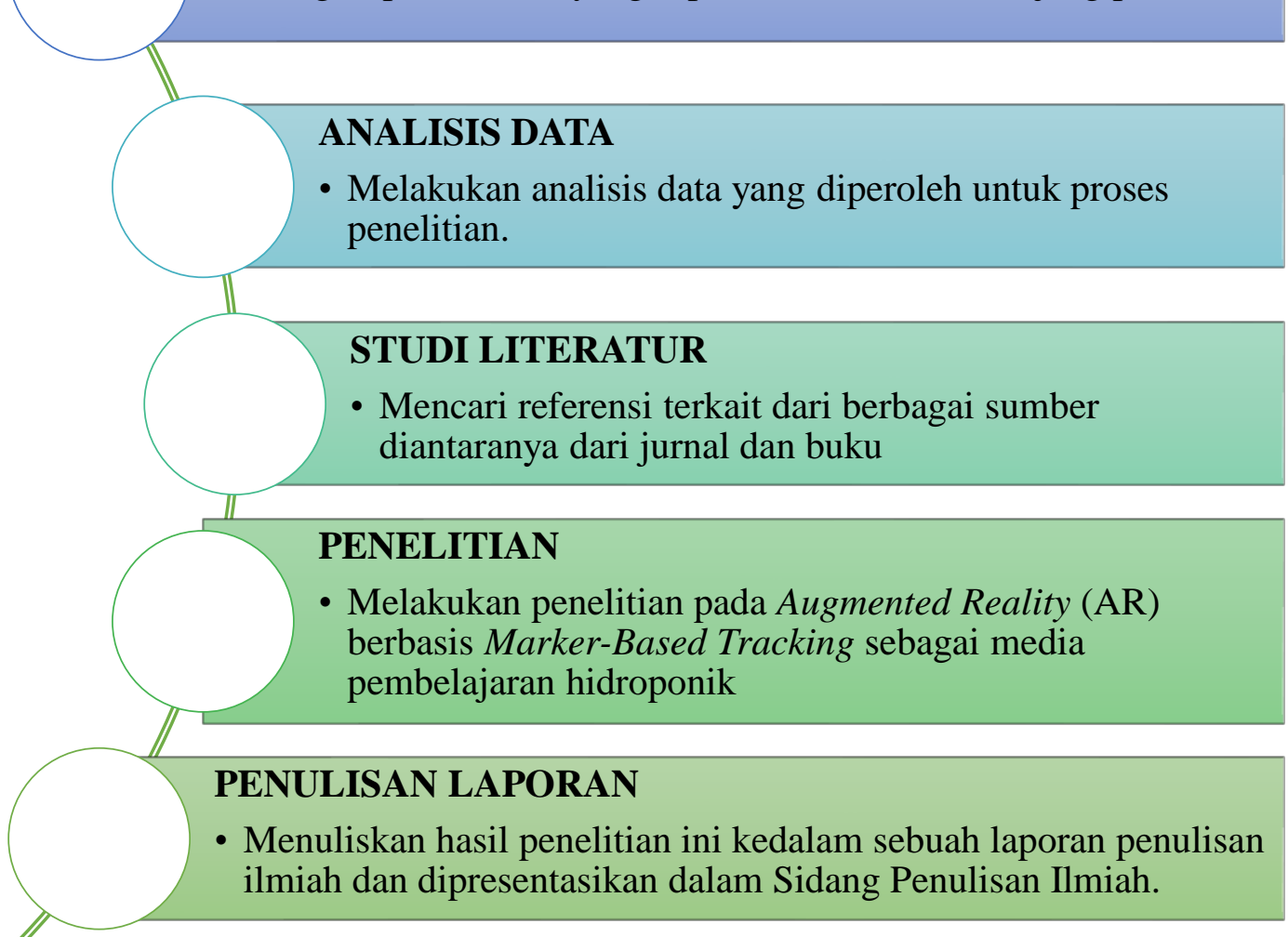

Gambar 1. 1. Kerangka Pemikiran. 


\subsection{Sistematika Penulisan}

Sistematika penulisan ini, menjelaskan secara singkat tentang susunan yang terdapat dalam penulisan ini. berikut uraian sistematika:

\section{PENDAHULUAN}

Pada pendahuluan ini, menjelaskan tentang latar belakang masalah, identifikasi masalah, batasan masalah, rumusan masalah, tujuan dan manfaat, kerangka pemikiran proposal penelitian ini serta sistematika penulisan.

\section{LANDASAN TEORI}

Pada landasan teori ini menjelaskan tentang berbagai macam referensi yang menjadi dalam penulisan, disertakan teori-teori pengenalan yang mengangkat tentang pendekatan yang digunakan.

\section{TUJUAN DAN MANFAAT PENELITIAN}

Pada Tujuan dan manfaat penelitian yang menjelaskan pandangan mengenai berbagai macam tujuan dan manfaat dari penulisan ilmiah.

\section{METODE PENELITIAN}

Pada metode penelitian ini berisi tentang metode atau pendekatan maupun teknik yang digunakan penulis dalam mengumpulkan data.

\section{HASIL ANALISA DAN PEMBAHASAN}

Berisikan tentang semua hasil kajian yang telah dilakukan, proses implementasi dari sistem.

\section{RENCANA PENELITIAN BERIKUTNYA}

Pada recana penelitian berikutnya ini menjelaskan tentang pengembangan atau perencanaan selanjutnya dari Penulisan Ilmiah yang akan dibuat di Tugas Akhir.

\section{KESIMPULAN DAN SARAN}

Pada kesimpulan dan saran ini menjelaskan tentang kesimpulan dari penjelasan sebelumnya, sehingga dari kesimpulan penulis mencoba 
memberikan saran yang berguna untuk melengkapi pengembangan sistem akademik pada sekolah selanjutnya.

\section{DAFTAR PUSTAKA}

\section{LAMPIRAN}




\section{LANDASAN TEORI}

\subsection{Tinjauan Pustaka}

Berikut ini penulis akan menguraikan tentang hasil penelitian yang berkaitan dengan sistem antrian dan juga penelitian tentang efisiensi sebuah proses ataupun perhitungan.

a. Implementasi Augmented Reality untuk Pembelajaran Interaktif (Dedy, 2017).

Penelitian ini menyajikan implementasi Augmented Reality (AR), untuk pembelajaran interaktif anak usia dini. Dengan menerapkan konsep AR pada metode pembelajaran anak usia dini, diharapkan dapat menciptakan suasana belajar yang menarik dan menyenangkan. Karena dengan menerapkan konsep AR pada metode pembelajaran para guru atau orang tua dapat menciptakan suasana belajar yang lebih nyata kepada anak dengan ditampilkannya objek 3D. , fokus penelitian ini ada pada tahap parallel play, assosiative play dan cooperative play. Dengan menggunakan media teknologi sebagai alat bantu untuk menarik fokus perhatian anak. Selain pada pemanfaatan teknologi objek-objek yang menjadi pusat pembelajaran/pengenalan di susun sebaik mungkin sesuai dengan lingkungan sekitar peserta didik. Sebagai contoh objek yang digunakan adalah pengenalan hewan dan buah-buahan. Di mana objek-objek tersebut dapat dengan mudah di temui oleh si anak, sehingga dapat terjadi keberlangsungan pembelajaran pada anak tersebut.

Penggunaan teknologi yang dimaksud adalah Augmented Reality (AR), yang merupakan sintesis perumpamaan nyata dan virtual. Aplikasi AR telah banyak diterapkan di berbagai aspek kehidupan, salah satu yang paling banyak adalah bidang pendidikan. Secara umum AR adalah konsep aplikasi yang menggabungkan dunia fisik (objek sesungguhnya) dengan dunia digital, tanpa mengubah bentuk objek fisik tersebut. Pengenalan objek (gambar) yang digunakan untuk menampilkan berbagai informasi mengenai objek tersebut berupa gambar 3D dan suara sesuai dengan karakter objek gambar. Augmented Reality sebagai sebuah sistem kognitif dan mampu memahami secara utuh persepsi dari pengguna. 
Tujuan penelitian ini adalah untuk mengembangkan media pembelajaran dengan memanfaatkan teknologi Augmented Reality, sehingga proses pembelajaran diharapkan lebih interaktif dengan dukungan visualisasi secara 3D untuk gambar, serta improvisasi suara untuk menciptakan realitas nyata pada proses pembelajaran. Objek pembelajaran yang dilakukan pada penelitian ini ditujukan kepada anak usia dini, baik yang tergabung melalui lembaga-lembaga pendidikan khusus untuk anak usia dini (PAUD), ataupun anak-anak secara mandiri dapat belajar dengan di damping oleh orang tua (/orang dewasa lain).

Penelitian ini telah mempresentasikan pengembangan media pembelajaran interaktif berbasis Augmented Reality (AR), yang diimplemetasikan untuk pembelajaran anak-anak usia dini. Aplikasi ini dikembangkan berdasarkan masukan dan saran dari beberapa lembaga pendidikan khususnya PAUD. Sehingga diharapkan para guru dan orang tua dapat terus memberikan masukan kontenkonten yang diberikan kepada anak-anak mereka. Diharapkan dengan menciptakan pembelajaran yang interaktif dan memberikan pengalaman user experience dapat memudahkan para guru dan orang tua dalam memberikan pemahaman kepada pengguna (anak-anak). Kedepan semoga akan banyak muncul model-model pembelajaran yang lebih nyaman untuk pengguna pada abad 21 ini, sehingga para guru dan orang tua tidak lagi memberikan konten-konten pembelajaran yang monoton kepada anak-anak.

b. Implementasi Augmented Reality Sebagai Pembelajaran Pertumbuhan Tanaman Dikotil Dan Monokotil Untuk Sekolah Dasar (Julia, Popy, \& Sitti, 2018).

Penelitian ini menjelaskan pembelajaran tanaman dikotil dan monokotil masih melakukan cara yang manual sehingga membuat siswa kurang memahami dalam belajar dan kurang menarik akan keingintahuannya, maka dari itu dibuatnya implementasi Augmented Reality. Augmented Reality adalah sebuah teknologi yang relatif baru dan masih dikembangkan pada saat ini. Konsepnya adalah menggaungkan dimensi dunia nyata dengan dimensi dunia virtual. Hal ini dilakukan dengan cara menggambarkan objek tiga dimensi pada marker, marker 
adalah sebuah pola segi empat yang bersifat unik dan dapat di kenali oleh aplikasinya. Pada penulisan ini menjelaskan bagaimana sebuah objek, yakni ciriciri tanaman dikotil dan monokotil serta macam tanaman dikotil dan monokotil di rancang untuk membantu guru sebagai media pembelajaran terhadap siswa sekolah dasar dapat mudah di pahami menggunakan Augmented Reality. Aplikasi ini bekerja dengan menggunakan kamera dimana kamera membaca marker dan objek akan tampil secara tiga dimensi. yang dapat diperoleh tentang implementasi Augmented Reality sebagai pembelajaran pertumbuhan tanaman dikotil dan monokotil untuk siswa sekolah dasar yaitu Aplikasi AR pertumbuhan tanaman dikotil dan monokotil dapat membantu guru dalam menjelaskan perbedaan ciri-ciri dari jenis tanaman dikotil dan monokotil, Implementasi objek pertumbuhan tanaman dikotil dan monokotil berupa objek 3D yang dapat di mengerti oleh siswa sekolah dasar, Aplikasi yang dibuat telah menjalankan fungsinya sebagai media pembelajaran pertumbuhan tanaman dikotil dan monokotil.

c. Perkembangan Teknologi Augmented Reality Sebagai Media Pembelajaran Interaktif Pada Mata Kuliah Kimia Dasar (Lia, 2015).

Augmented Reality (AR) adalah adalah teknologi yang menggabungkan benda maya tiga dimensi (3D) ke dalam sebuah lingkungan nyata tiga dimensi Model 3 dimensi biasa digunakan sebagai alat bantu pengajaran untuk membuat para peserta didik lebih memahami materi yang diberikan. Teknologi AR sudah diaplikasikan dalam berbagai bidang yang beragam, termasuk dalam bidang pendidikan. salah satu mata kuliah yang bisa mengaplikasikan teknologi AR adalah mata kuliah kimia dasar. Saat ini mata kuliah kimia dasar merupakan mata kuliah yang tidak menyenangkan bagi peserta didik, terutama bagi mahasiswa fakultas tekhnik tingkat pertama yang mendapat mata kuliah ini. Salah satu penyebabnya adalah kimia mempunyai banyak konsep yang sukar untuk dipahami dan dibayangkan, seperti struktur atom dan bentuk molekul dalam ikatan kimia. Sehingga dibutuhkan media pembelajaran alternatif dalam rangka meningkatkan pemahaman konsep kimia secara interaktif. Pada mata kuliah kimia dasar terdapat beberapa materi dasar yang membutuhkan imajinasi yang tinggi untuk bisa memahami materi tersebut seperti materi atom dan molekul, sistem periodik, ikatan 
kimia, hidrokarbon dan beberapa materi lainnya. AR memberikan interaksi yang lebih realistis dan merupakan kemajuan dari sebuah metoda teknologi yang menjanjikan dan bisa memotivasi pengguna untuk terlibat dalam sistem pembelajaran yang lebih aktif. Pembelajaran kimia merupakan pembelajaran yang cukup sulit terutama dalam memahami karakteristik struktur dalam skala atom. Penggunaan teknologi AR merupakan teknologi yang menguntungkan dalam proses belajar mengajar. Dengan penggunaan teknologi AR diharapkan dapat membantu pengguna baik dosen maupun mahasiswa untuk lebih berinteraksi secara nyata dan interaktif.

\subsection{Tinjauan Studi}

Adapun tinjauan studi pada penelitian ini yaitu:

\subsubsection{Implementasi}

Implementasi adalah perluasan aktivitas yang saling menyesuaikan proses interaksi antara tujuan dan tindakan untuk mencapainya serta memerlukan jaringan pelaksana, birokrasi yang efektif. (Guntur, 2004)

\subsubsection{Augmented Reality}

Pengertian Augmented Reality Azuma dalam karya ilmiahnya berjudul $A$ survey of Augmented Reality (2007), dalam (Indriani \& Sugiato, 2016) menjelaskan bahwa Augmented Reality adalah teknologi yang menggabungkan obyek-obyek maya yang ada dan dihasilkan (generated) oleh komputer dengan benda-benda yang ada di dunia nyata sekitar kita, dan dalam waktu yang nyata. Dengan bantuan Augmented Reality lingkungan sekitar akan menjadi seperti bentuk digital yang membuat lingkungan tidak nyata disekitar menjadi seolah-olah nyata (digital). (Indriani \& Sugiato, 2016).

Augmented Reality(AR) adalah istilah untuk lingkungan yang menggabungkan dunia nyata dan dunia virtual yang dibuat oleh komputer sehingga batas antara keduanya menjadi sangat tipis. Sistem ini lebih dekat kepada lingkungan nyata (real). Reality lebih diutamakan pada sistem ini. Sistem ini 
berbeda dengan Virtual Reality (VR) yang sepenuhnya merupakan Virtual Environment. Dengan teknologi AR lingkungan nyata disekitar akan dapat berinteraksi dalam bentuk digital (virtual). Informasi tentang objek dan lingkungan sekitar dapat ditambahkan kedalam sistem AR yang kemudian akan ditampilkan pada layar dunia nyata secara real-time seolah-olah informasi tersebut nyata. AR memiliki banyak potensi didalam industri dan penelitian akademis. (Candra, Rachmawati, \& Budiman, 2014)

AR merupakan sebuah teknologi yang menggabungkan benda maya baik 2D maupun 3D ke dalam lingkungan nyata lalu memproyeksikan benda-benda maya tersebut dalam waktu nyata. (Roedavan, 2014), Augmented Reality adalah penggabungan benda-benda nyata dan maya di lingkungan nyata, berjalan secara interaktif dalam waktu nyata, dan terdapat integrasi antar benda dalam tiga dimensi, yaitu benda maya terintegrasi dalam dunia nyata. Ia juga mendefinisikan Augmented Reality sebagai sistem yang memiliki karakteristik sebagai berikut: (a) Menggabungkan lingkungan nyata dan virtual; (b) Berjalan secara interaktif dalam waktu nyata; dan (c) Berintegrasi dalam tiga dimensi (3D).

Tujuan dari AR adalah mengambil dunia nyata sebagai dasar dengan menggabungkan beberapa teknologi virtual dan menambahkan data konstektual agar pemahaman manusia sebagai penggunanya menjadi semakin jelas. Data konstektual ini dapat berupa komentar audio, data lokasi, konteks sejarah, atau dalam bentuk lainnya. Pada saat ini, AR telah banyak digunakan dalam berbagai bidang seperti kedokteran, militer, manufaktur, hiburan, museum, Game pendidikan, pendidikan, dan lain-lain. (Rahmat, 2011)

Dalam perkembangannya AR telah digunakan pada beberapa bidang kehidupan. bidang - bidang yang telah menggunakan AR antara lain:

\section{a. Kedokteran (Medical)}

Teknologi pencitraan sangat dibutuhkan di dunia kedokteran, seperti misanya, untuk simulasi operasi, simulasi pembuatan vaksin virus, dll. Untuk itu, bidang kedokteran menerapkan Augmented Reality pada visualisasi penelitian mereka. 
b. Hiburan (Entertainment)

Dunia hiburan membutuhkan Augmented Reality sebagai penunjang efekefek yang akan dihasilkan oleh hiburan tersebut. Sebagai contoh, ketika sesorang wartawan cuaca memperkirakan ramalan cuaca, dia berdiri di depan layar hijau atau biru, kemudian dengan teknologi Augmented Reality, layar hijau atau biru tersebut berubah menjadi gambar animasi tentang cuaca tersebut, sehingga seolah-olah wartawan tersebut, masuk ke dalam animasi tersebut.

c. Latihan Militer (Military Training)

Militer telah menerapkan Augmented Reality pada latihan tempur mereka. Sebagai contoh, militer menggunakan Augmented Reality untuk membuat sebuah permainan perang, dimana prajurit akan masuk kedalam dunia Game tersebut, dan seolah-olah seperti melakukan perang sesungguhnya.

d. Engineering Design

Seorang engineering design membutuhkan Augmented Reality untuk menampilkan hasil design mereka secara nyata terhadap klien. Dengan Augmented Reality klien akan tahu, tentang spesifikasi yang lebih detail tentang desain mereka.

e. Consumer Design

Virtual reality telah digunakan dalam mempromsikan produk. Sebagai contoh, seorang pengembang menggunkan brosur virtual untuk memberikan informasi yang lengkap secara $3 \mathrm{D}$, sehingga pelanggan dapat mengetahui secara jelas, produk yang ditawarkan. (Andriyadi \& Anggi, 2011)

Dalam pembuatan AR beberapa komponen penting yang diperlukan dalam pembuatan dan pengembangan aplikasi AR adalah sebagai berikut:

a. Komputer

Komputer berfungsi sebagai perangkat yang digunakan untuk mengendalikan semua proses yang akan terjadi dalam sebuah aplikasi penggunaan komputer ini disesuaikan dengan kondisi dari aplikasi yang akan digunakan. Kemudian untuk output aplikasi akan ditampilkan melalui layar monitor maupun layar pada ponsel. 
b. Marker

Marker berfungsi sebagai gambar (image) yang akan digunakan computer untuk proses tracking pada saat aplikasi digunakan. Komputer akan mengenali posisi dan orientasi dari marker dan akan menciptakan objek virtual yang berupa objek 3D.

c. Kamera

Kamera merupakan perangkat yang berfungsi sebagai recording sensor. Kamera terhubung dengan komputer dan akan memproses image yang ditangkap oleh kamera. Apabila kamera mengangkap image yang mengandung marker, maka aplikasi yang ada di komputer akan mengenali marker. Selanjutnya komputer akan mengkalkulasikan posisi dan jarak marker tersebut. Lalu, komputer akan menampilkan objek 3D di atas marker tersebut.

Secara umum AR berfungksi untuk memvisualisasikan suatu objek dalam waktu yang bersamaan (realtime). Adapun lebih spesifik lagi fungsi AR sebagai berikut: (1) Mengkombinasikan objek fisik dan digital interface. Dan (2) Menciptakan manipulasi dari model objek virtual. (Pratama, 2014)

Secara garis besar, skema kerja AR adalah sebagai berikut: video atau kamera yang digunakan pada aplikasi AR menangkap image marker yang lebih dahulu di identifikasi. Setelah posisi dan orientasi marker terdeteksi maka hasil perhitungan tersebut dimasukkan ke dalam matriks. Matriks ini kemudian dipakai untuk menentukan virtual kamera relatif terhadap marker (Rahmat, 2011).

\subsubsection{Definisi Hidroponik}

Hidroponik adalah istilah yang digunakan untuk menjelaskan beberapa cara bercocok tanam tanpa menggunakan tanah sebagai tempat menanam tanaman (Lingga, 1984).

Hidroponik menjadi sebuah alternatif bagi masyarakat yang ingin berkebun namun tidak memiliki cukup tempat untuk bercocok tanam. Hidroponik adalah lahan budidaya pertanian tanpa menggunakan media tanah, sehingga hidroponik merupakan aktivitas pertanian yang dijalankan dengan menggunakan air sebagai 
medium untuk menggantikan tanah. Namun bercocok tanam dengan cara hidroponik ini perlu penanganan, perawatan dan pemantauan yang lebih dibandingkan dengan bercocok tanam konvensional dengan media tanah. Sehingga pemilik perlu untuk memberikan perhatian lebih kepada tanamannya. (Ibadarrohman, Nur , \& Anacotiana, 2018). Hydroponic secara harfiah berarti Hydro adalah air, dan phonic adalah pengerjaan. Sehingga secara umum berarti system budidaya pertanian tanpa menggunakan tanah tetapi menggunakan air yang berisi larutan nutrisi. Budidaya hidroponik biasanya dilaksanakan di dalam rumah kaca (greenhouse) untuk menjaga supaya pertumbuhan tanaman secara optimal dan benar - benar terlindung dari pengaruh unsur luar seperti hujan, hama penyakit, iklim dan lain-lain.

Keunggulan dari beberapa budidaya dengan menggunakan sistem hidroponik antara lain:

a. Keberhasilan tanaman untuk tumbuh dan berproduksi lebih terjamin.

b. Perawatan lebih praktis dan gangguan hama lebih terkontrol.

c. Pemakaian pupuk lebih hemat (efisien).

d. Tanaman yang mati lebih mudah diganti dengan tanaman yang baru.

e. Tidak membutuhkan banyak tenaga kasar karena metode kerja lebih hemat dan memiliki standarisasi.

f. Tanaman dapat tumbuh lebih pesat dan dengan keadaan yang tidak kotor dan rusak.

g. Hasil produksi lebih continue dan lebih tinggi disbanding dengan penanama ditanah.

h. Harga jual hidroponik lebih tinggi dari produk non-hydroponik.

i. Beberapa jenis tanaman dapat dibudidayakan di luar musim.

j. Tidak ada resiko kebanjiran,erosi, kekeringan, atau ketergantungan dengan kondisi alam.

k. Tanaman hidroponik dapat dilakukan pada lahan atau ruang yang terbatas, misalnya di atap, dapur atau garasi. 
Jenis hidroponik dapat dibedakan dari media yang digunakan untuk berdiri tegaknya tanaman. Media tersebut biasanya bebas dari unsur hara (steril), sementara itu pasokan unsur hara yang dibutuhkan tanaman dialirkan ke dalam media tersebut melalui pipa atau disiramkan secara manual. Media tanam tersebut dapat berupa kerikil, pasir, gabus, arang, zeolite atau tanpa media agregat (hanya air). Yang paling penting dalam menggunakan media tanam tersebut harus bersih dari hama sehingga tidak menumbuhkan jamur atau penyakit lainnya. Dan juga system hidroponik ini mempunyai beberapa kelemahan yaitu: (1) Investasi awal

yang mahal. Dan (2) memerlukan keterampilan khusus untuk menimbang dan meramu bahan kimia. Ketersediaan dan pemeliharaan perangkat hidroponik agak sulit (Roidah, 2014).

\subsubsection{Unity 3D}

Unity merupakan alat pengembangan game yang didesain untuk membiarkan penggunanya focus dalam mengembangkan game yang bagus. Unity merupakan pilihan yang tepat bagi studio kecil, pengembangan indie, dan bagi mereka yang ingin membuat game sendiri. Unity memiliki basis pengguna yang banyak (lebih dari 40.000 orang pada bulan April 2001) dan komunitas pemakai yang aktif dimana memungkinkan semua orang awam bertukar pengalaman dari para veteran. Unity membuka peluang pada Windows pada musim semi tahun 2009. Sejak saat itu, unity terus memberikan.

Dukungan pada iPhone, Andorid, Ipad, dan dukungan pada Xbox 360 dan PS3. Adapter awal dari engine unity cenderung untuk berpindah dari Flash dan Director, membuat scripting menjadi lebih mudah diterapkan. Sementara pemakai unity memiliki latar belakang ActionScript dalam membuat game Flash. Ada banyak bahan untuk membuat game memakai Unity, meliputi game first person shooting, game balap, platform jumper, dan sejenisnya (Yulianto, 2012). 


\subsubsection{Vuforia}

Vuforia merupakan software untuk Augmented Reality yang dikembangkan oleh Qualcomm, yang menggunakan sumber yang konsisten mengenai computer vision yang fokus pada image recognition. Vuforia mempunyai banyak fitur-fitur dan kemampuan, yang dapat membantu pengembang untuk mewujudkan pemikiran meraka tanpa adanya batas secara teknikal. Dengan support untuk iOS, Android, dan Unity 3D, platform Vuforia mendukung para pengambang untuk membuat aplikasi yang dapat digunakan di semua jenis smartphone dan tablet. Augmented Reality Vuforia memberikan cara berinteraksi yang memanfaatkan kamera mobile phones untuk digunakan sebagai perangkat masukan, sebagai mata elektronik yang mengenali pananda tertentu, sehingga di layar bisa ditampilkan perpaduan antara dunia dan dunia yang digambar oleh aplikasi. Dengan kata lain, Vuforia adalah SDK untuk computer vision based AR.

Menurut (Pratama, 2014) Vuforia pada Augmented Reality adalah Software Development Kit (SDK) untuk perangkat mobile yang memungkinkan pembuatan aplikasi Augmented Reality. Menggunakan teknologi Computer Vision untuk mengenali dan melacak gambar planar (Image Target) dan objek 3D sederhana, seperti kotak, secara real-time. Kemampuan registrasi gambar ini memungkinkan pengembang untuk memposisikan dan mengarahkan objek virtual, seperti model 3D dan media lainnya, terkait dengan gambar dunia nyata saat dilihat melalui kamera perangkat seluler. Objek virtual kemudian melacak posisi dan orientasi gambar secara real-time sehingga sudut pandang pemirsa pada objek sesuai dengan perspektif mereka pada Image Target, sehingga tampak bahwa objek virtual adalah bagian dari dunia nyata

\subsubsection{Arsitektur Vuforia}

Vuforia SDK memerlukan beberapa komponen penting agar dapat bekerja dengan baik. Komponen-komponen tersebut anatara lain (Fernando, 2013): 
a. Kamera

Kamera dibutuhkan untuk memastikan bahwa setiap frame ditangkap dan diterukan secara efisien ke tracker. Para developer hanya tinggal memberi tahu kamera kaoan mereka mulai menagkap dan berhasil.

\section{b. Image Converter}

Mengkonvensi format kamera (misal: YUV12) kedalam format yang dapat dideteksi oleh OpenGL (misal : RGB565) dan untuk tracking (misal : luminance).

c. Tracking

Menggabungkan algoritma compute vision yang dapat mendeteksi dan melacak objek dunia nyata yang ada pada video kamera. Berdasarkan gambar dari kamera, algoritma yang berbeda bertugas untuk memdeteksi trackable baru, dan mengevakuasi visual button. Hasil akan disimpan dalam state object yang akan digunakan oleh background renderer dan dapat diakses dari Aplication code.

\section{d. Video Background Renderer}

Me-render gambar dari kamera yang tersimpan didalam state objek. Performa dari video background renderer sangat bergantung pada device yang digunakan.

\section{e. Application Code}

Menginisialisasi semua komponen diatas dan melakukan tiga tahapan penting dalam application code seperti: (1) Query state object pada target baru yang terdeteksi atau marker; (2) Update logika aplikasi setiap input baru dimasukan; dan (3) Rende grafis yang ditambahkan (augmented).

\section{f. Target Resources}

Dibuat menggunakan online target management system. Assets yang diunduh berisi sebuah konfigurasi $x m l$ config. $x m l$ yang memungkinkan developer untuk mengkonfirmasi beberapa fitur dalam trackable dan binary file yang berisi database trackble.

\section{g. Trackables}


Trackables adalah kelas dasar yang mewakili semua benda dunia nyata bahwa SDK Vuforiadapat melacak six degreesof-freedom. Setiap trackble, ketika dideteksi dan dilacak, memiliki nama, ID, status, dan pose informasi. Target gambar, gambar multie target dan marker, semua Trackables yang mawarisi sifat dari kelas dasar. Trackables yang diperbaharui setiap frame diproses, dan hasilnya diteruskan ke aplikasi pada state object.

h. Marker

Dalam pembuatan marker dalam hal ini markerless diperlukan sebuah file gambar. JPG yang nantinya akan di upload ke vuforia, marker yang telah di upload akan dinilai kualitasnya oleh sistem.

\subsubsection{Pembelajaran}

Pembelajaran pada hakekatnya digunakan siswa untuk mengembangkan potensi pada dirinya (Susilana \& Riyana, 2008). Kegiatan pembelajaran melibatkan dua belah pihak yaitu peserta didik sebagai penerima pendidikan dan pendidik sebagai pemberi fasilitas. Keutamaan dalam kegiatan pembelajaran adalah terjadinya proses belajar (Susilana \& Riyana, 2008). Menurut (Sanaky, 2013), pembelajaran merupakan suatu proses interaksi antara pembelajar, pengajar dan bahan ajar. (Kustandi \& Sutjipto, 2013), mengemukakan bahwa pembelajaran merupakan proses suatu rencana dalam rangka mengelola sumber belajar agar terjadi proses belajar pada siswa. (Suprihatiningrum, 2013), mendefinisikan pembelajaran sebagai serangkaian kegiatan yang yang terencana dengan melibatkan informasi dan lingkungan.

\subsubsection{Media}

Media adalah semua bentuk perantara yang digunakan oleh manusia untuk menyampaikan atau menyebar ide, gagasan atau pendapat, sehingga ide, gagasan atau pendapat yang dikemukakan itu sampai kepada penerima yang dituju. (Arsyad, 2002). 


\section{TUJUAN DAN MANFAAT PENELITIAN}

\subsection{Tujuan Penelitian}

Adapun tujuan yang ingin dicapai dalam penelitian ini adalah:

a. Untuk mengetahui dan memahami bagaimana pengimplementasian Augmented Reality untuk media pembelajaran

b. Untuk mengetahui cara Augmented Reality dalam pembelajaran menanam hidroponik.

c. Untuk mengetahui ke efektifan Augmented Reality di implementasikan dalam proses pembelajaran.

\subsection{Manfaat Penelitian}

Adapun manfaat yang di ambil dalam penelitian ini adalah sebagai berikut:

a. Manfaat Teoritis

Hasil dari penelitian ini dapat menjadi landasan dalam pengembangan media pembelajaran selain itu juga menjadi sebuah media pembelajaran yang interaktif.

b. Manfaat Praktis

1) Hasil penelitian ini diharapkan dapat meningkatkan pemahaman konsep Augmented Reality dan penerapannya pada aplikasi pembelajaran hidroponik berbasis Android.

2) Dapat membantu dalam mempelajari cara menanam hidroponik. 


\section{METODE PENELITIAN}

\subsection{Metode Pengumpulan Data}

Metode penelitian atau metode ilmiah adalah prosedur atau lagkah-langkah dalam mendapatkan pengetahuan ilmiah atau ilmu. Jadi metode penelitian adalah cara sistematis untuk menyususn ilmu pengetahuan. Sedangkan teknik penelitian adalah cara untuk melaksanakan metode penelitian. Metode penelitian biasanya mengacu pada bentuk-bentuk penelitian. (Prof. Dr. Suryana, M.SI., 2010).

Metode yang digunakan pada penelitian ini adalah metode observasi. Observasi adalah suatu cara pengumpulan data dengan pengamatan langsung dan pencatatan secara sistematis terhadap obyek yang akan diteliti. (Arikunto, 2010)

Metode pengumpulan data merupakan tahap paling penting dalam sebuah penelitian. Karena pada tahap ini peneliti menjelaskan cara pengumpulan informasi serta apa yang dilakukan untuk informasi tersebut. Pada penelitian ini Ada beberapa metode yang digunakan untuk mendapatkan data/informasi diantaranya:

\subsubsection{Observasi}

Obrservasi merupakan salah satu teknik pengumpulan data yang tidak hanya mengukur sikap dari responden, namun juga dapat digunakan untuk merekam berbagai fenomena yang terjadi (situasi, kondisi). Teknik ini digunakan bila penelitian ditujukan untuk mempelajari perilaku manusia, proses kerja, gejalagejala alam dan dilakukan pada responden yang tidak terlalu besar.

Dalam mengumpulkan data ini, peneliti melakukan pengamatan langsung pada proses hidroponik di green house universitas bandar lampung untuk mengetahui proses dari penanaman hidroponik maupun alat-alat yang dibutuhkan dalam penanaman hidroponik, untuk itu peneliti melakukan pengamatan langsung pada hari kamis tanggal 24 januari 2019 pada pukul 10.00 WIB. Dengan di damping salah satu pegembang green house. Hasil pengamatan peneliti akan ditampilkan dalam bentuk table, dalam tabel tersebut memuat alat-alat yang digunakn dan alur cara menanam hidroponik. 
Tabel 4. 1. Hasil Observasi.

\begin{tabular}{|c|c|}
\hline Alat- alat hidroponik & Alur menanam hidroponik \\
\hline Nampan, rockwoll, biji tanaman & $\begin{array}{l}\text { a. Pembibitan } \\
\text { Dalam proses pembibitan yang } \\
\text { pertama dilakukan membuat } \\
\text { lubang pada rockwoll kurang lebih } \\
0,5 \mathrm{~cm} \text { disusun satu persatu } \\
\text { rockwoll pada nampan setelah itu } \\
\text { masukan biji pada rockwoll yang } \\
\text { telah di lubangi setelah itu biarkan } \\
\text { selama kurang lebih } 14 \text { hari } \\
\text { dengan selalu membuat rockwoll } \\
\text { keadaan basah. }\end{array}$ \\
\hline Talang hidroponik, net pot, pompa air & $\begin{array}{l}\text { b. Pembesaran } \\
\text { Setelah pembibitan dilakukan } \\
\text { pemindahan ke talang hidroponik } \\
\text { yang telang kita buat selama } \\
\text { proses ini dibutuhkan air agar } \\
\text { rockwoll selalu keadaan basah } \\
\text { selain itu selalu memeriksa } \\
\text { kesehatan tanaman dengan salah } \\
\text { satu nya memberi nutrisi } A B \text { mix } \\
\text { maupun mengecek ph air. }\end{array}$ \\
\hline & $\begin{array}{l}\text { c. Pemanenan } \\
\text { Setelah kurang lebih } 30 \text { hari } \\
\text { tananaman dapat di panen. }\end{array}$ \\
\hline
\end{tabular}




\subsubsection{Studi Literatur}

Studi literatur adalah mencari referensi teori yang relefan dengan kasus atau permasalahan yang ditemukan. Referensi ini dapat dicari dari buku, jurnal, artikel laporan penelitian, dan situs-situs di internet. Output dari studi literatur ini adalah terkoleksinya referensi yang relefan dengan perumusan masalah. Referensi tersebut berisikan tentang:
a. Augmented Reality secara umum
b. Proses Penanaman Hidroponik
c. Aplikasi unity

Kkebutuhan yang dilakukan secara intensif untuk mespesifikasikan kebutuhan perangkat lunak agar dapat dipahami seperti apa yang dibutuhkan oleh user.

\subsection{Analisis Kebutuhan}

Analisis kebutuhan adalah suatu proses untuk mendapatkan informasi, mode, spesifikasi tentang perangkat lunak yang diinginkan klien/pengguna. Kedua belah pihak, yaitu klien dan pembuat perangkat lunak terlibat aktif dalam tahap ini. Informasi dari klien yang akan menjadi acuan untuk melakukan desain perangkat lunak.

Tahap ini dilakukan agar apa yang akan dibuat atau dirancang sesuai dengan kebutuhan sistem yang berdasarkan data-data pada tahap-tahap perancangan. Analisa kebutuhan meliputi kebutuhan perangkat keras dan perangkat lunak.

\subsection{Rancangan Penelitian}

\subsubsection{Analisis Sistem}

Dalam AR, informasi ditingkatkan atau ditambahkan dengan menggabungkan antara realitas dan objek maya yang telah didesain sebelumnya. Dengan AR pengguna dapat berinteraksi dengan dunia nyata secara bersamaan menggunakan komputer/gadget untuk mengeksplorasi informasi dan berinteraksi 
dengan benda-benda virtual. Biasanya AR mempunyai karakteristik yaitu: menggabungkan real dan virtual, real-time, dan berupa objek 3D. Contoh dalam penggunaan AR pada sistem Android dapat dilihat pada Aplikasi Augmented Reality pembelajaran buah-buahan adalah sebuah aplikasi berbasis mobile yang dapat berjalan pada sistem operasi Android (Alfi, Meyti, \& Sandi, 2016).

Aplikasi ini menggunakan metode Marker-Based Tracking sebagai penanda untuk menampilkan objek 3D. Marker nantinya akan menggunakan media kertas untuk membantu pelacakan yang dilengkapi dengan keterangan nama, warna, vitamin, dan manfaat dalam bahasa Inggris.

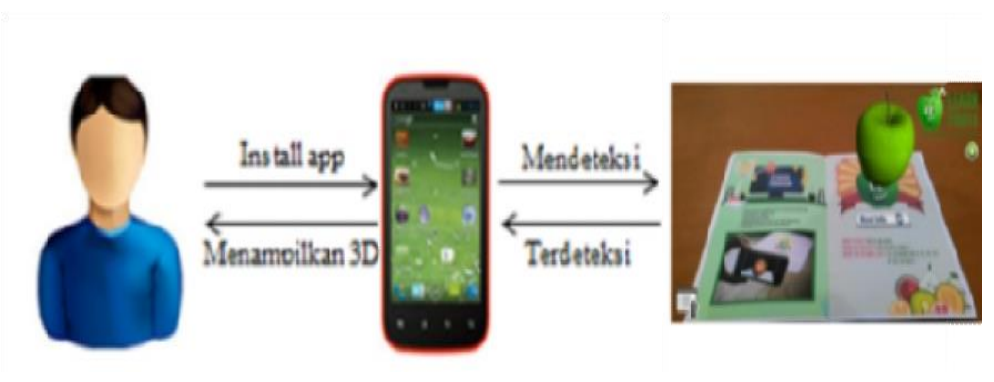

Gambar 4.1. Deskripsi Umum Sistem AR

Aplikasi Augmented Reality pembelajaran buah-buahan pada sistem, lalu sistem mendeteksi marker. Setelah marker terdeteksi oleh sistem, sistem dapat menampilkan objek 3D pada layar. Ini adalah salah satu contoh bagaimana sebuah aplikasi AR bekerja pada sebuah marker.

\subsubsection{Metode Marker-Based Tracking}

Marker-Based Tracking merupakan metode Augmented Reality yang mengenali marker dan mengidentifikasi pola dari marker tersebut untuk menambahkan suatu objek virtual ke lingkungan nyata (Chari \& Narayana, 2008) . Marker merupakan ilustrasi persegi hitam dan putih dengan sisi hitam tebal, pola hitam ditengah persegi dan latar belakang putih. Contoh marker dapat dilihat pada gambar dibawah. 


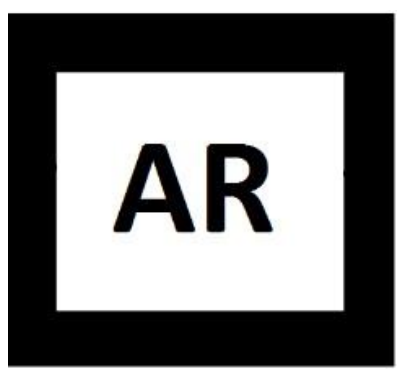

Gambar 4. 2. Contoh Marker

Titik koordinat virtual pada marker berfungsi untuk menentukan posisi dari objek virtual yang akan ditambahkan pada lingkungan nyata. Posisi dari objek virtual akan terletak tegak lurus dengan marker. Objek virtual akan berdiri segaris dengan sumbu $\mathrm{Z}$ serta tegak lurus terhadap sumbu X (kanan atau kiri) dan sumbu Y (depan atau belakang) dari koordinat virtual marker. Ilustrasi dari titik koordinat virtual marker dapat dilihat pada gambar 3.

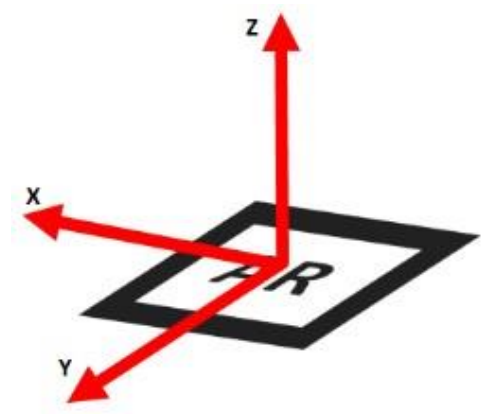

Gambar 4. 3. Titik Kordinat Virtual pada Marker

Proses tracking dimulai dari tahap inputImage. Tahap ini merupakan tahap dimana prosesor mengolah secara realtimeframe per frame dari video hasil tangkapan perangkap tangkapan. Tahap berikutnya adalah thresholding image, pada tahap ini tiap frame video mengalami proses thresholding sehingga menghasilkan gambar hitam putih. Tahap ini bertujuan untuk mengenali bentuk segi empat dan pola marker dari video yang telah ditangkap (Christoper, 2012). 
Proses tracking adalah marker detection atau pendeteksian marker, pada tahap interdiri dari empat proses, yaitu : contours extraction, corner detection, pattern normalization dan template matching. Proses contours extraction dan corner detection dapat dilihat pada gambar 4

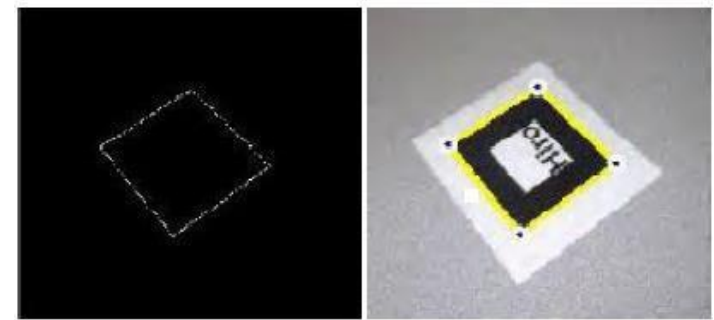

Gambar 4. 4. Contours Extracition dan Corner Detection

Proses contours extraction dan corner detection memanfaatkan gambar hitam putih yang didapat pada tahap kedua untuk mendapatkan koordinat dari empat sisi dan empat titik sudut marker (Christoper, 2012) terdapat pada gambar 5

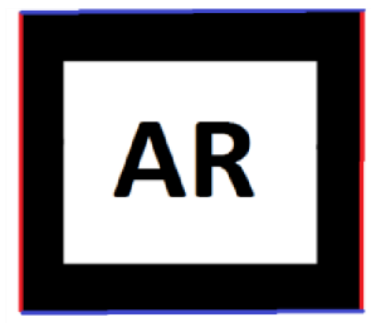

Gambar 4. 5. Dua Garis Paralel pada Marker

Dua proses berikutnya pada tahap markerdetection adalah pattern normalizatiion dan template matching dapat dilihat pada gambar 6. Proses pattern normalization bertujuan menormalisasikan bentuk marker sehingga proses template matching dapat dilakukan dengan tepat.

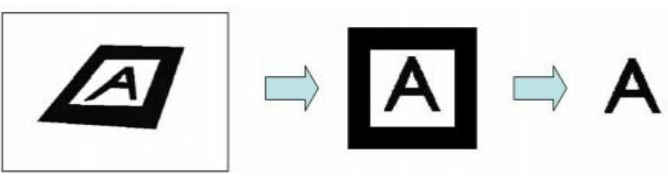

Gambar 4. 6. Pattern Normalization dan Template Matching 
Tahap terakhir adalah tahap pose and position estimation. Tahap ini yang bertanggung jawab dalam peletakan objek virtual di atas marker. Pada tahap ini hubungan antar tiga koordinat memegang peranan penting, yaitu koordinat dari perangkat tampilan (observed screen coordinates). (Christoper, 2012) Sistem koordinat dapat dilihat pada gambar 7.

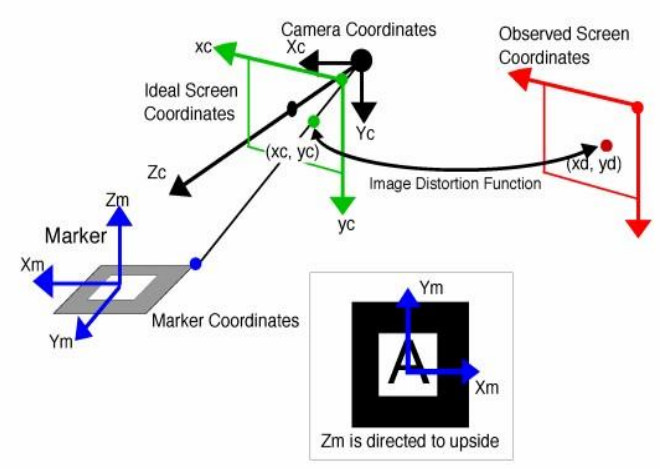

Gambar 4. 7. Sistem Koordinat

Pada tahap ini dilakukan proses transformasi yang dibutuhkan untuk mendapatkan posisi kamera relatif terhadap marker dalam koordinat dari penangkapan video.

Pembuatan Augmented Reality menggunakan beberapa metode salah satunya adalah Marker-Based Tracking. Secara default, marker memang menggunakan bingkai hitam dengan pola yang berada di bagian tengah bingkai, akan tetapi dalam perkembangannya, marker tidak harus hitam putih.

Seperti Aplikasi Augmented Reality pembelajaran buah buahan menggunakan marker dengan konsep berwarna (Alfi, Meyti, \& Sandi, 2016) dalam memunculkan objek 3D.Komputer akan mengenali posisi dan orientasi marker dan menciptakan dunia virtual 3D yaitu titik $(0,0,0)$ dan 3 sumbu yaitu $\mathrm{X}, \mathrm{Y}$, dan $\mathrm{Z}$. Marker akan terekam melalui kamera secara realtime. Kemudian marker digunakan untuk mengenali objek yang akan ditambahkan. Objek yang ditambahkan akan diproses menggunakan komputer dan webcam yang kemudian ditampilkan dalam layar maupun peralatan display khusus (smartphone) melalui pengenalan sebuah marker (Djuniarto, 2013). 


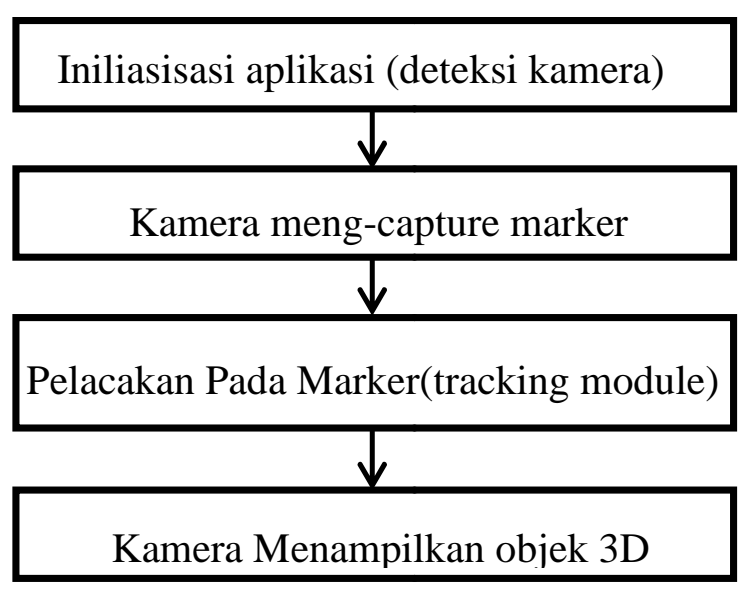

Gambar 4. 8. Alur Sistem Metode Based Marker Tracking

\subsection{Penanaman Hidroponik}

Beberapa jenis hidroponik yang umum digunakan antara lain (Sastro \& Rokhmah, 2016) :

a. Wick System

Sistem ini merupakan model hidroponik yang paling sederhana, yaitu menggunakan sumbu yang menghubungkan pot tanaman dengan media larutan nutrisi.

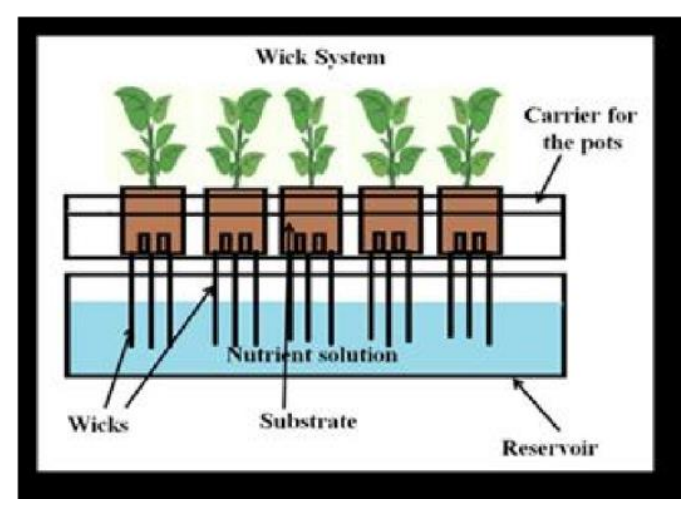

Gambar 4. 9.Hidroponik dengan Wick System

\section{b. Nutrient Film Technique (NFT)}

Larutan nutrisi secara terus menerus dialirkan mengenai akar tanaman menggunakan pipa PVC menggunakan pompa dengan teknik resirkulasi. 


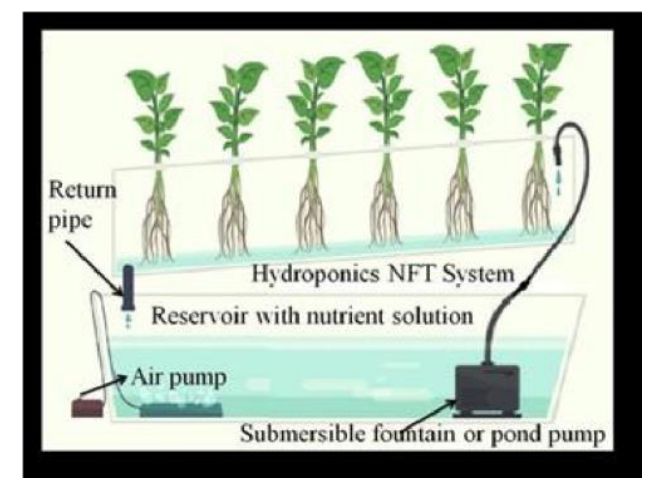

Gambar 4. 10.Hidroponik dengan NFT System

\section{c. Deep Water Culture (DWC)}

Tanaman dibuat mengapung pada larutan nutrisi sehingga akar tanaman terendam terus menerus. Penggunaan pompa hanya untuk menghasilkan oksigen di dalam larutan nutrisi.

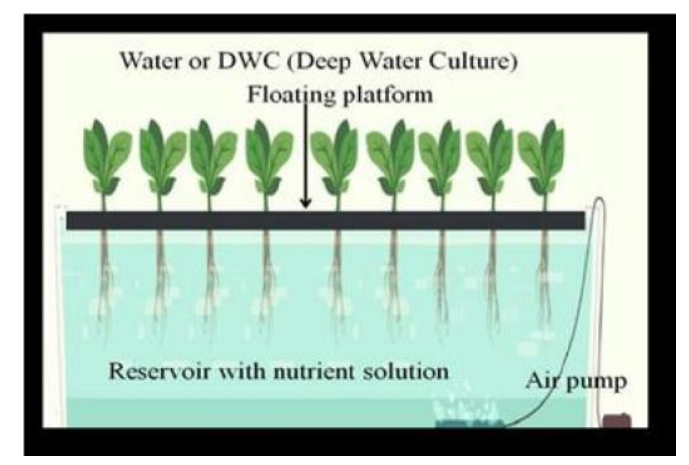

Gambar 4. 11.Hidroponik dengan DWC System

\section{d. Drip System}

Sistem ini menggunakan 2 (dua) buah kontainer terpisah yaitu bagian atas dan bawah. Kontainer atas untuk tanaman dan yang bawah untuk larutan nutrisi. Larutan nutrisi dipompa naik dan menyiram batang tanaman dan akan larutan sisa akan turun ke kontainer bawah setelah melewati media tanam dan akar tanaman. 


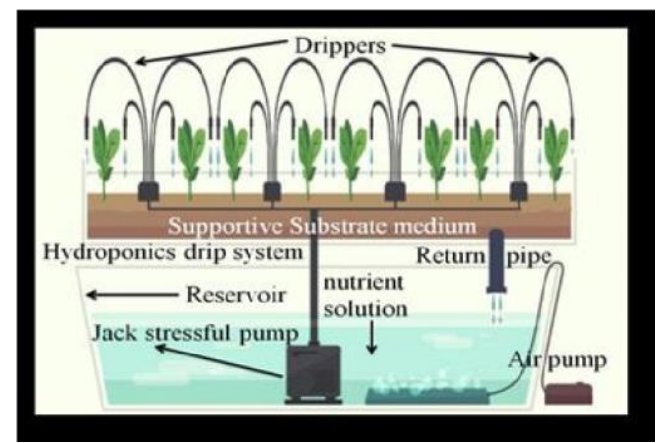

Gambar 4. 12.Hidroponik dengan Drip System

\section{e. Ebb and Flow Systems (Flood and Drain System)}

Pengaturannya mirip dengan sistem infus, di mana ada dua kontainer, yang satu di atas berisi tanaman dalam pot dengan substrat dan yang ada di bagian bawah yang mengandung larutan nutrisi. Pemberian nutrisi untuk tanaman dilakukan dengan sistem pasang surut, yaitu bergantian memenuhi kontainer atas dengan larutan nutrisi dan kemudian mengosongkan larutan nutrisi dan kembali ke kontainer bawah.

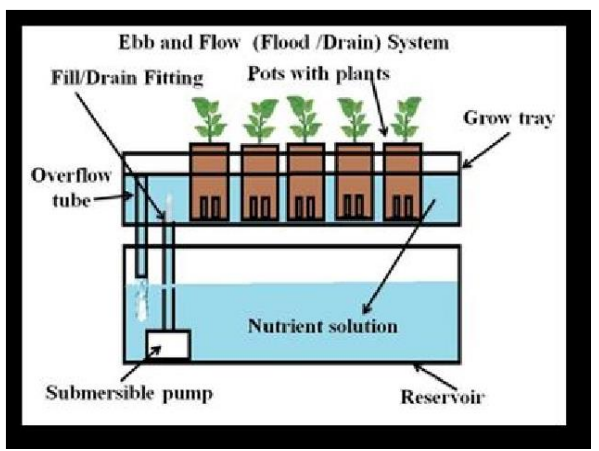

Gambar 4. 13.Hidroponik dengan Ebb and Flow System Media Tumbuh

Media tumbuh yang ideal untuk hidroponik antara lain dapat menopang pertumbuhan tanaman, memiliki pori untuk aerasi, tidak menyumbat instalasi hidroponik, dan tidak mempengaruhi larutan nutrisi. Media tidak berfungsi menyediakan nutrisi dan harus bersifat lembab. Media tanam selain tanah yang dapat digunakan antara lain air, busa, kerikil, rockwool, pasir, serbuk gergaji, gambut, sabut kelapa, perlit, batu apung, kulit kacang, poliester, atau vermikulit (Purbajanti dkk, 2017). 


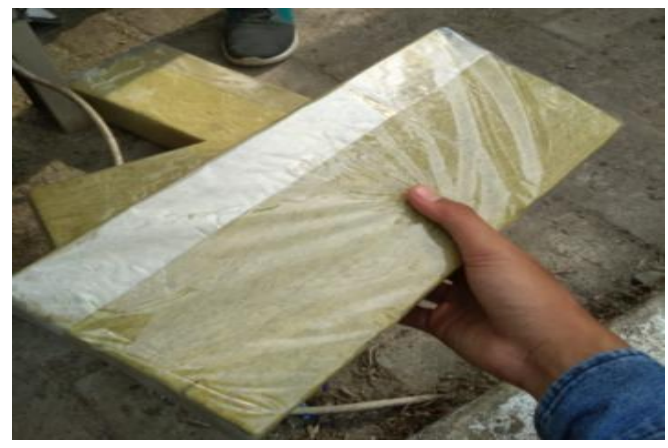

Gambar 4. 14.Media tanam rockwool

\subsubsection{Instalasi Hidroponik}

Nutrient Film Technique (NFT). Model ini paling disukai karena perkembangan tanaman paling cepat, karena hanya ujung akar yang bersentuhan dengan larutan nutrisi sehingga oksigen juga lebih banyak diserap dari udara .

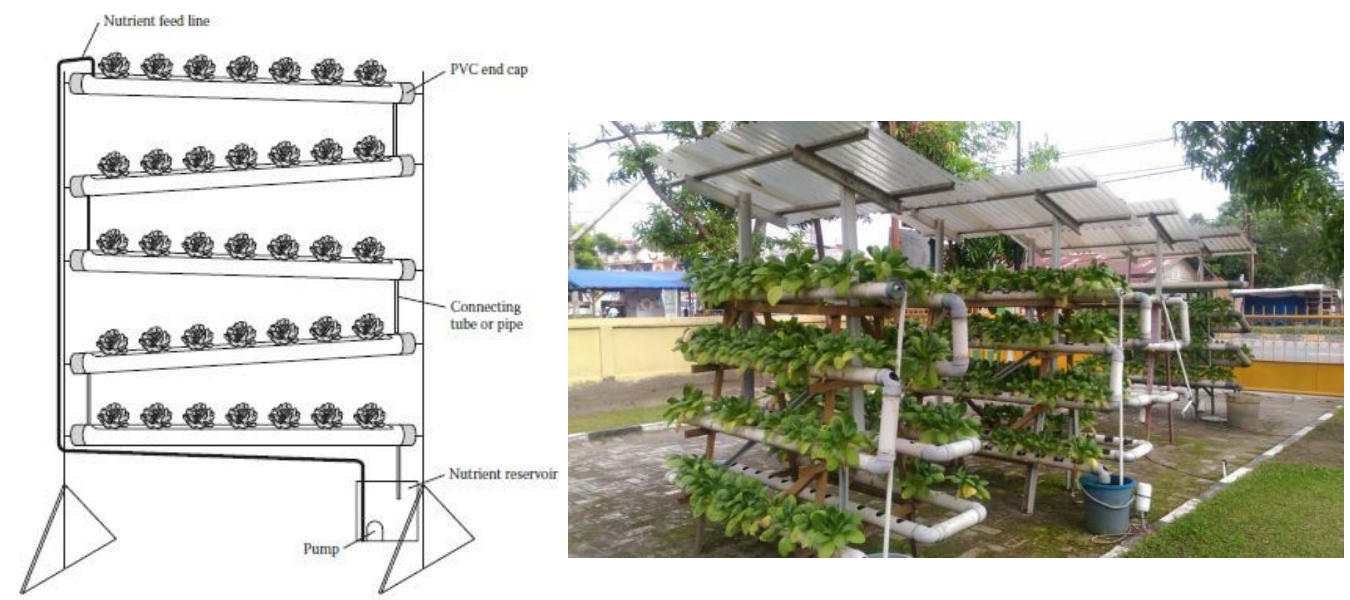

Gambar 4. 15.Model Hidroponik NFT

Model ini dapat dimodifikasi sesuai dengan keinginan atau kebutuhan. Rak dapat dibuat bertingkat dan atau bersusun seperti piramid atau dapat juga disusun melebar. Air mengalir secara gravitasi dari bagian tinggi ke rendah. Oleh karena itulah ketinggian talang air diukur demgam kemiringan 2-3\%. Untuk mengalirkan nutrisi menggunakan pompa maka nutrisi yang digunakan dimasukkan ke dalam bak penampung dengan debit air 1 liter/menit (Tallei \& dkk, 2017) 
Bahan yang dibutuhkan antara lain (Tallei \& dkk, 2017) :
a. Talang Air
b. Penutup talang atau styrofoam
c. Kran pembuka dan penutup 0,5 inci.
d. Pipa PVC 0,5 inci ; 1 inci ; dan 2 inci.
e. Selang plastik 3-5 mm.
f. Knee T 0.5 inci; 1 inci; dan 2 inci.
g. Pompa air aquarium.
h. Solartuff atau atap plastik.
i. Boks kontainer (Bak - Dop 0.5 inci, 1 inci, 2 inci penampung)
j. Tutup Talang

\subsubsection{Larutan Nutrisi}

Bahan baku pupuk hidroponik berupa garam anorganik atau garam kimia yang dapat dibeli di toko kimia atau toko pertanian. Nutrisi hidroponik biasanya menggunakan konsep formulasi AB mix. Yaitu kalsium pada grup A dan tidak bertemu sulfat dan fosfat pada grup B.

Tabel 4. 2 Komposisi nutrisi hidroponik.

\begin{tabular}{|c|c|}
\hline AB-Mix Sayuran Daun & AB-Mix Sayuran Buah : \\
\hline $\begin{array}{l}\text { Komposisi Pekatan A } \\
\text { a. Kalsium nitrat: } 1176 \text { gram } \\
\text { b. Kalium nitrat: } 616 \text { gram } \\
\text { c. Fe EDTA: } 38 \text { gram }\end{array}$ & $\begin{array}{l}\text { Komposisi Pekatan A } \\
\text { a. Kalsium nitrat: } 1100 \text { gram } \\
\text { b. Kalium nitrat: } 575 \text { gram } \\
\text { c. Fe EDTA: } 38 \text { gram }\end{array}$ \\
\hline $\begin{array}{l}\text { Komposisi B } \\
\text { a. Kalium dihidro fosfat: } 335 \text { gram } \\
\text { b. Amnonium sulfat: } 122 \text { gram } \\
\text { c. Kalium sulfat: } 36 \text { gram } \\
\text { d. Magnesium sulfat: } 790 \\
\text { e. Cupri sulfat: } 0,4 \text { gram } \\
\text { f. Zinc sulfat: } 1,5 \text { gram } \\
\text { g. Asam borat: } 4,0 \text { gram } \\
\text { h. Mangan Sulfat: } 8 \text { gram } \\
\text { i. Amonium hepta molibdat : } 0,1 \text { gram }\end{array}$ & $\begin{array}{l}\text { Komposisi B } \\
\text { a. Kalium dihidro fosfat: } 560 \text { gram } \\
\text { b. Amnonium sulfat: } 30 \text { gram } \\
\text { c. Kalium sulfat: } 75 \text { gram } \\
\text { d. Magnesium sulfat: } 1.050 \text { gram } \\
\text { e. Cupri sulfat: } 0,4 \text { gram } \\
\text { f. Zinc sulfat: } 1,5 \text { gram } \\
\text { g. Asam borat: } 4,0 \text { gram } \\
\text { h. Mangan Sulfat: } 8 \text { gram } \\
\text { i. Amonium hepta molibdat : } 0,1 \text { gr }\end{array}$ \\
\hline
\end{tabular}


Untuk AB mix model ini, $5 \mathrm{ml}$ larutan A dan $5 \mathrm{ml}$ larutan B dicampurkan lagi ke dalam 1 liter air kemudian diaduk rata. Larutan encer ini siap digunakan untuk nutrisi hidroponik yang ditanam. Untuk membuat 10 liter larutan siap pakai berarti diperlukan $50 \mathrm{ml}$ larutan pekat $\mathrm{A}$ dan $50 \mathrm{ml}$ larutan pekat $\mathrm{B}$, demikian seterusnya setiap liter yang diperlukan dikalikan 5 .

Dari 5 liter larutan pekatan A dan B ini dapat diperoleh sebanyak 1000 liter larutan hidroponik siap pakai. Tentunya tidak semua harus langsung dilarutkan, namun disesuaikan dengan kebutuhan.

\subsubsection{Persiapan Tanam}

Bahan tanam dibagi dalam 2 kelompok yaitu generatif dan vegetatif. Cara generatif dilakukan dengan menggunakan biji, sedangkan cara vegetatif dengan sambungan (grafting/entring) atau stek (cutting). Untuk sayuran umumnya adalah secara generatif menggunakan biji yang dapat ditanam secara langsung maupun dengan persemaian. Secara langsung yaitu biji yang siap ditanam, atau sebagai benih, langsung disebar pada lahan atau areal pertanaman. Persemaian atau pembibitan yaitu menanam benih pada tempat khusus terlebih dahulu sampai pada umur tertentu tergantung dari jenis tanamannya. Biasanya benih untuk persemaian ini berasal dari sayuran yang berbiji halus. Secara umum tujuan dari persemaian ini adalah untuk memperoleh bibit yang baik dan seragam. Namun tidak begitu saja usaha persemaian ini selalu berhasil baik, disini sangat diperlukan perawatan dan pengawasan sampai pada tahap pemindahan bibit.

Penanaman menggunakan benih secara langsung dilakukan dengan cara memasukan benih ke dalam media tanam dengan menggunakan pinset. Setelah itu netpot hidroponik diletakan di dalam set hidroponik yang digunakan. Penanaman menggunakan bibit dilakukan dengan cara mengambil bibit secara hati-hati dari wadah pembibitan, kemudian bagian akar diselimuti menggunakan media tanam, dan selanjutnya diletakan ke dalam set pot yang telah diatur pada set hidroponik. 


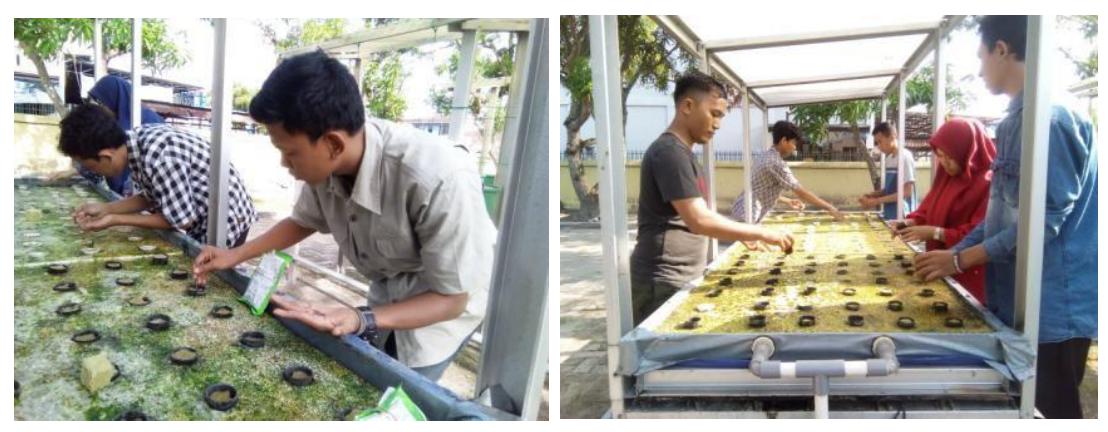

Gambar 4.15. Penanaman benih langsung ke media tanam

\subsubsection{Pemeliharaan Tanaman}

Menjaga aerasi dan sanitasi di lingkungan hidroponik juga menjadi syarat penting agar tanaman tumbuh baik. Hal-hal yang perlu diperhatikan antara lain (Tallei \& dkk, 2017):

a. Pengukuran $\mathrm{pH}$ dan Nutrisi

$\mathrm{pH}$ penting diketahui untuk mengatur serapan unsur hara tanaman agar tidak terjadi defisiensi. Kadar nutrisi dalam larutan dapat diukur dengan TDS (Total Dissolved Solids) atau PPM (Parts Per Millions). Hasil pengukuran menunjukkan nilai EC larutan yang sangat menentukan kecepatan metabolisme tanaman yaitu jika nutrisi yang diberikan sesuai dengan kebutuhan tanaman.

b. Pengendalian Hama dan Penyakit

Hama yang sering menyerang tanaman hidroponik adalah kutu putih, kutu Aphid, siput, lalat pengorok daun dan semut. Jenis penyakit pada tanaman hidroponik umumnya sama dengan tanaman yang dibudidayakan di tanah. Penyebab penyakit disebabkan oleh jamur, bakteri dan virus yang ditularkan melalui vektor serangga ataupun penggunaan alat-alat tanam yang terkontaminasi. Gulma bukan merupakan masalah karena teknik hidroponik meminimalisir tumbuhnya gulma. 
c. Penyulaman

Penyulaman tanaman dapat dilakukan pada umur tanaman 15 HST.

d. Pengontrolan instalasi

Sistem pompa dan selang/pipa yang tidak lancar akan sangat berpengaruh pada pertumbuhan tanaman. Listrik dan air yang tidak tersedia menyebabkan kegagalan budidaya jika dibiarkan dalam waktu lama.

e. Panen dan Pasca Panen

Masing-masing komoditas memiliki umur panen dan perlakuan panen yang berbeda. Untuk skala bisnis sangat penting untuk memperhatikan waktu panen dan penanganan pascapanen yang tepat. 


\section{HASIL ANALISA DAN PEMBAHASAN}

\subsection{Analisis Kebutuhan}

Augmented Reality (AR) adalah istilah untuk lingkungan yang menggabungkan dunia nyata dan dunia virtual yang dibuat oleh komputer sehingga batas antara keduanya menjadi sangat tipis. ). Pada Augmented Reality ini membutuhkan kamera pada smartphone sebagai media input untuk membaca marker (penanda khusus), dimana dari marker tersebut akan menampilkan informasi berupa teks dan gambar 3 dimensi pada layar smartphone.. Pada analisa kebutuhan, tersusun dari bagaimana kebutuhan yang dibutuhkan aplikasi dalam proses pembuatannya. Yaitu dengan perangkat lunak (software) dan perangkat keras (hardware) yang dibutuhkan dalam pembuatan aplikasi ini. Selain sistem operasi yang menjadi software dasar dari software - software lain, perancangan program untuk para pengembang sistem operasi Android membutuhkan software software pendukung diantaranya adalah JDK, ADT Plugin, Android SDK, Vuforia Qualcomm, Unity 3D.

Tabel 5. 1. Kebutuhan Perangkat Lunak (Software)

\begin{tabular}{|l|l|}
\hline Perangkat Lunak & Keterangan \\
\hline Sistem operasi Windows 10 & $\begin{array}{l}\text { Sistem operasi yang digunakan dalam } \\
\text { pembuatan aplikasi }\end{array}$ \\
\hline Vuvoria Master Package 2-5-8 & $\begin{array}{l}\text { Library Augmented Reality yang digunakan } \\
\text { untuk membuat aplikasi }\end{array}$ \\
\hline $\begin{array}{l}\text { Android Development tools } \\
\text { (ADT plig-in) }\end{array}$ & $\begin{array}{l}\text { Plug-in yang digunakan untuk } \\
\text { mengintegrasikan } \text { eclipse enjadi lingkungan } \\
\text { pengembangan Android }\end{array}$ \\
\hline $\begin{array}{l}\text { Android SDK (Software } \\
\text { Development Kit) }\end{array}$ & Tools pengembang pogram Android \\
\hline Unity 3D & $\begin{array}{l}\text { Antarmuka program berupa objek 3D dan } \\
\text { video }\end{array}$ \\
\hline SkechUp & Pembuatan dan pengeditan objek 3D \\
\hline
\end{tabular}


Tabel 5. 2. Kebutuhan Perangkat Keras (Hardware)

\begin{tabular}{|l|l|}
\hline Perangkat keras(Hardware $)$ & Keterangan \\
\hline \multirow{3}{*}{ Komputer } & Spesifikasi yang digunakan \\
& a. Prosesor Intel core i5 \\
& b. Ram 4 GB \\
& c. Harddisk 500 GB \\
\hline
\end{tabular}

\subsection{Augmented Reality Sebagai Media Pembelajaran Hidroponik}

Saat ini banyak alternatif dalam media pembelajaran salah satu nya dengan teknologi Augmented Reality (AR) yang dapat dimanfaatkan sebagai media pembelajaran hidroponik hal ini dikarenakan perlu pemahaman khusus dalam merawat tanaman hidroponik dengan kelebihhan dari (AR) yang menampilkan objek 3 dimensi ataupun animasi membuat terlihat seperti nyata sehingga dapat memahami pelajaran dengan Augmented Reality berbasis Marker-Based Tracking yang apabila aplikasi dengan kamera yang di arahkan ke marker akan menampilakan objek 3 dimensi dari tahapan-tahapan dari alur menanam hidroponik sebagai berikut:

a. Pembibitan

Dalam tahapan ini akan menampilkan animasi dari tunas pada sebuah yang mulai tumbuh serta akan diberi informasi tentang alat yang digunakan pada tahap ini dan waktu dari tahap pembibitan.

b. Pembesaran

Tahapan ini pemindahan bibit dari tempat yang kecil ke tempat yang besar yaitu ke talang hidroponik dalam tahapan ini akan menampilkan gambaran tempat yang digunakan dan menampilkan animasi dari tumbuhan yang mulai besar tahapan ini juga menampilkan informasi perawatan dari hidroponik seperti nutrisi yang diperlukan tanaman

c. Pemanenan

Dalam tahapan ini akan menampilkan tumbuhan dan informasi jangka waktu yang tepat untuk memanen 


\subsection{Analisis Sistem dan Pembahasan}

Setelah melakukan Analisis penulisan ini akan menjelaskan dan menjabarkan hasil Analisis yang sudah dilakukan tentang Augmented Reality menggunakan marker yang diimplementasikan pada penelitian ini.

\subsubsection{Analisis Marker-Based Tracking}

Marker/penanda yang digunakan dalam penelitian ini adalah sebuah gambar selada dimana dalam metode Marker-Based Tracking merupakan metode Augmented Reality yang mengenali marker dan mengidentifikasi pola dari marker tersebut untuk menambahkan suatu objek virtual ke lingkungan nya.

Dalam pengembangannya marker tidak harus berbentuk persegi dan berwarna hitam putih seperti yang dibuat peneliti menggunakan gambar selada sebagai media marker dengan begitu marker akan terlihat lebih menarik

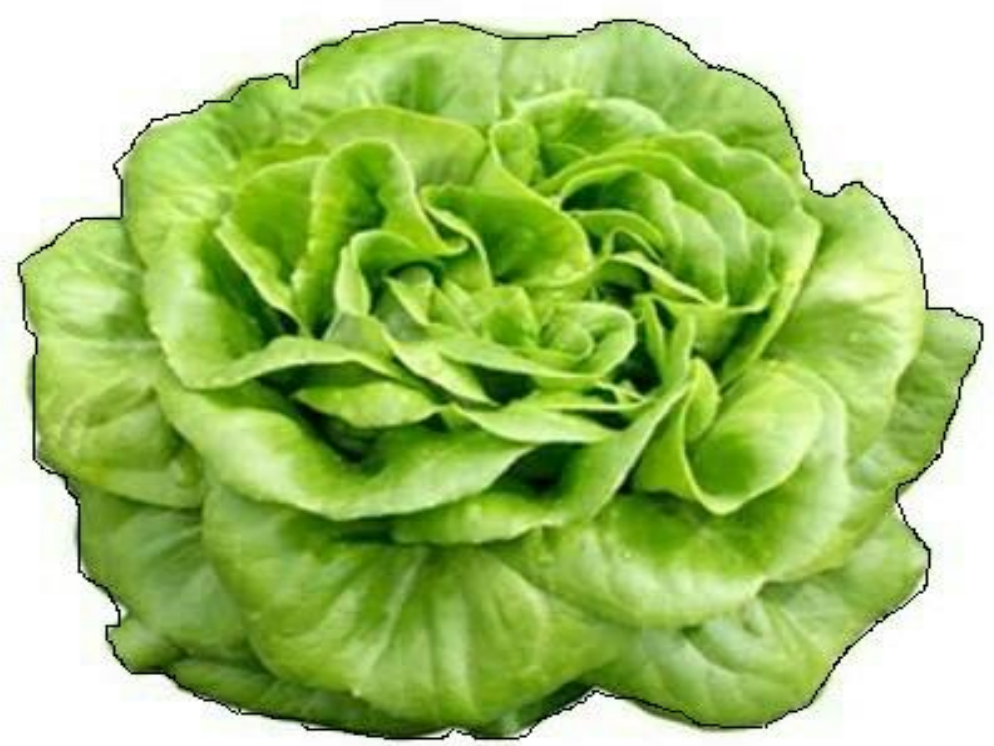

Gambar 5.1. Marker Gambar Selada

Setelah tahap pengindentifikasi pola selanjutnya adalah titik kordinat virtual pada marker berfungsi untuk menentukan posisi dari objek virtual yang akan ditambahkan pada lingkungan nyata. Posisi dari objek virtual akan terletak tegak lurus dengan marker. 
Objek virtual akan berdiri segaris dengan sumbu $\mathrm{Z}$ serta tegak lurus terhadap sumbu X (kanan atau kiri) dan sumbu Y (depan atau belakang) dari koordinat virtual marker Ilustrasi dari titik koordinat virtual marker dapat dilihat pada gambar dibawah.

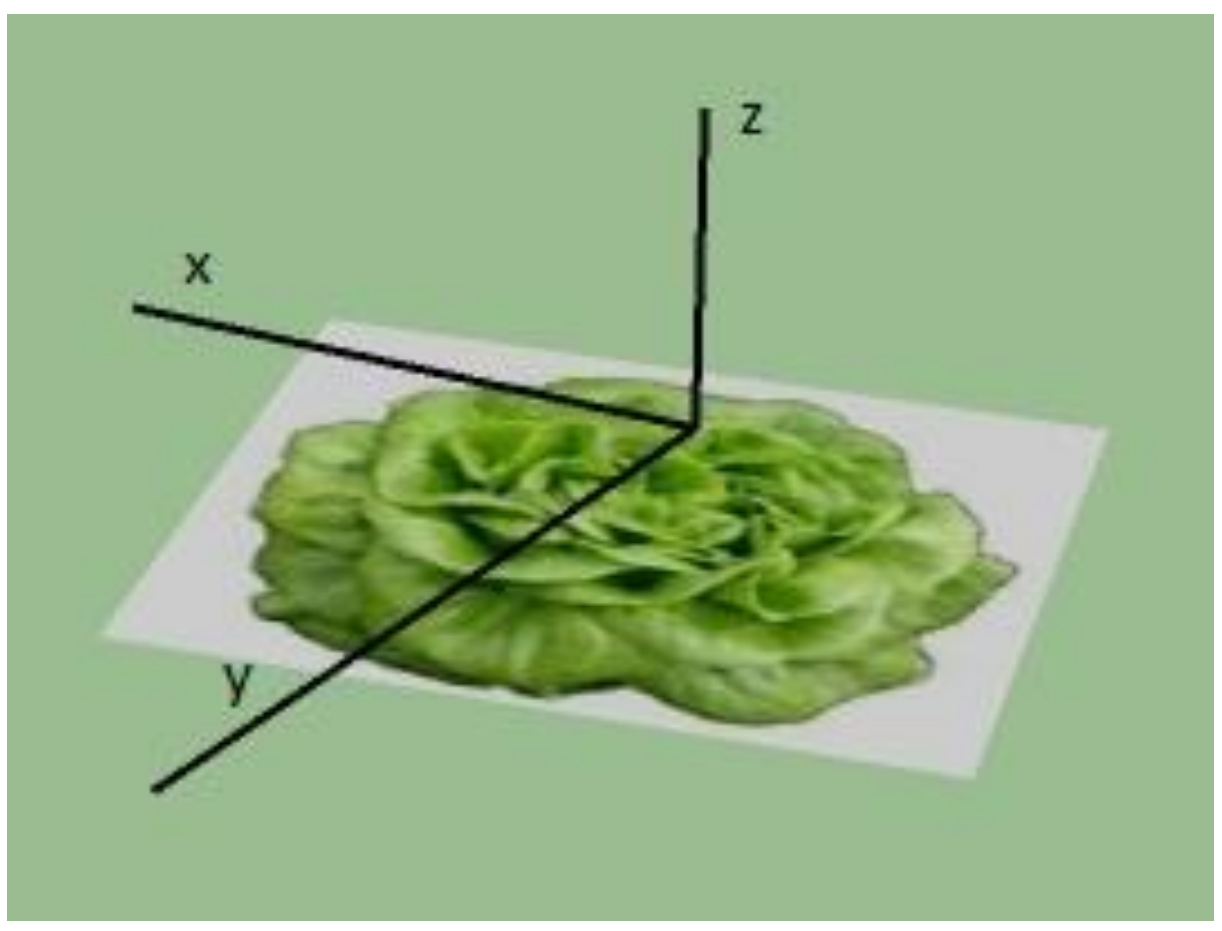

Gambar 5. 2. Ilustrasi dari Titik Kordinat.

Berikut ini adalah gambaran alur Augmented Reality Marker-Based Tracking 


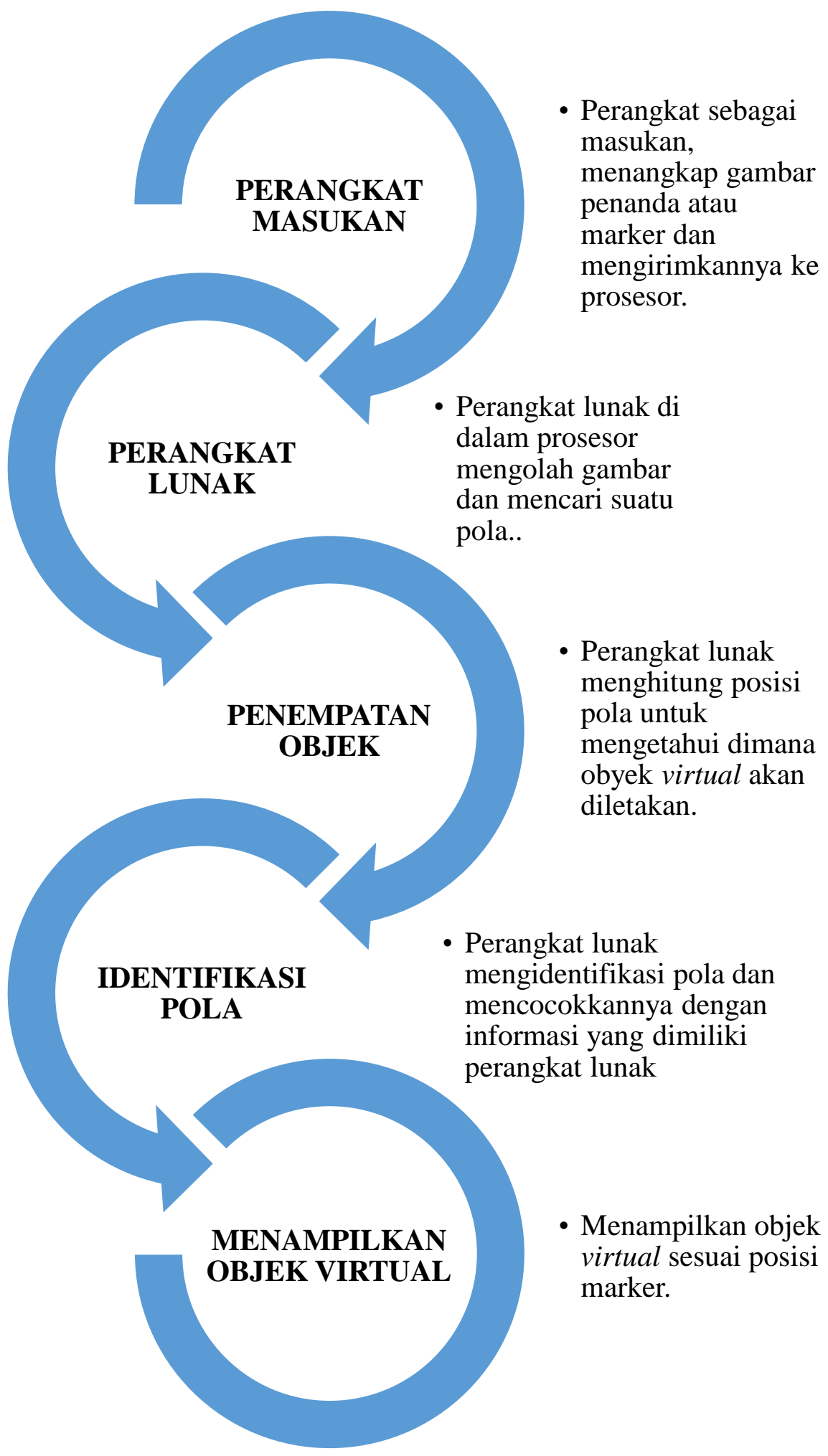

Gambar 5. 3. Alur Augmented Reality Marker-Based Tracking 


\subsubsection{Objek Augmented Reality}

Dalam aplikasi ini objek yang mucul adalah Objek 3 dimensi berbentuk selada memiliki tampilan objek padat, dengan ditambah tulisan 3 dimensi sebagai informasi dalam tampilan ini objek terlihat nyata yang membuat teliahat menarik dan mudah dipahami. Dengan ini tampilan objek 3 dimensi ini harapannya akan dapat membantu dalam penjelasan suatu objek Seperti yang terlihat pada gambar.

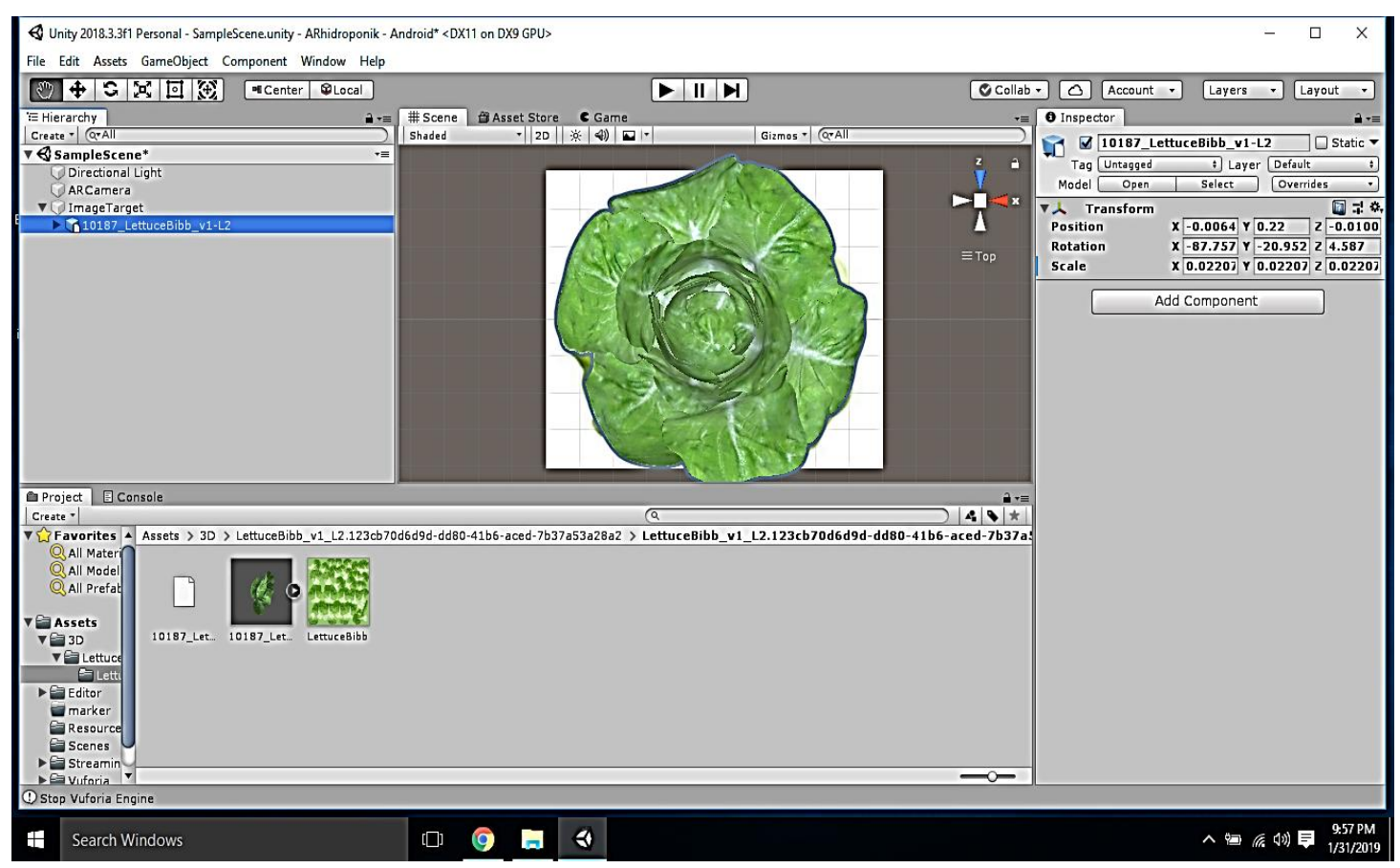

Gambar 5. 4. Tampilan Objek.

\subsubsection{Implemtasi Augmented Reality Media Pembelajaran Hidroponik}

Hasil dari analisis di terapkan pada implemtasi ini Salah satu objek 3 dimensi. Saat AR kamera pada smartphone diarahkan pada marker yang telah kita buat tadi maka objek 3 dimensi selada akan tampil pada smartphone seperti yang terlihat pada gambar dibawah ini. 


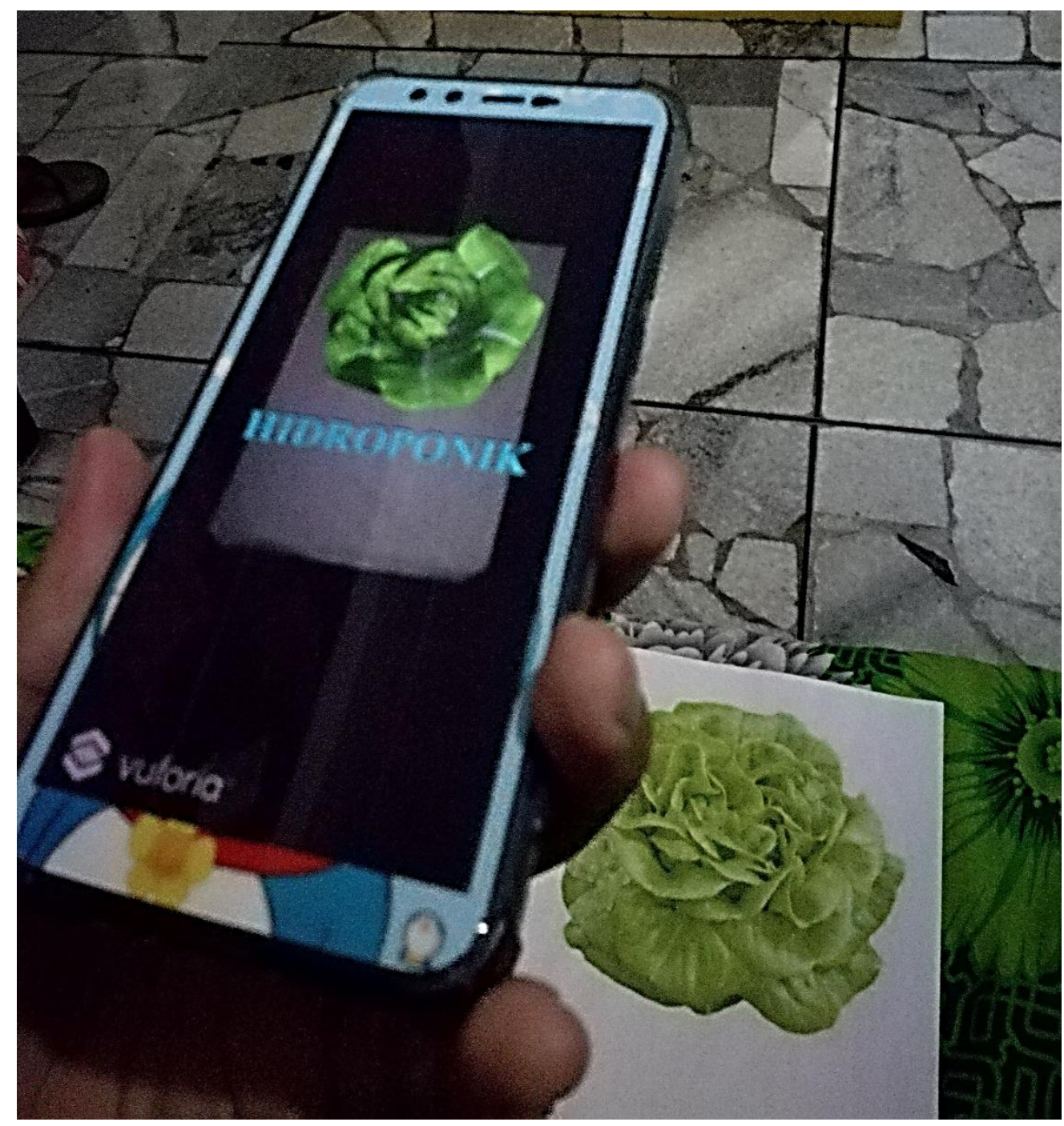

Gambar 5. 5. Tampilan Objek Virtual di Smartphone.

\section{$5.4 \quad$ Uji Validasi}

Uji validasi dilakukan guna mengetahui faktor apa saja yang cukup berpengaruh dalam pendektesian marker.

\section{a. Uji Pencahayaan}

Pencahayaan menjadi faktor yang paling penting dalam pendektesian marker, cahaya yang dapat ditangkap oleh lensa kamera berperan penting karena apabila menampilakan marker ke kamera pada saat kondisi cahaya gelap, ataupun kondisi cahaya sangat terang/silau maka kamera akan susah dalam mengenali marker dan objek virtual tidak dapat tampil, 
Dalam pengujian menggunakan lux light meter, lux meter adalah alat yang digunakan untuk mengukur besarnya intensitas cahaya di suatu tempat. Besarnya intensitas cahaya ini diketahui dengan. Semakin jauh jarak dengan sumber cahaya maka semakin kecil nilai yang ditunjukkan lux meter. Ini membuktikan bahwa semakin jauh jarak terhadap cahaya, maka intensitas cahaya akan semakin berkurang, begitu sebaliknya, jika semakin dekat dengan sumber cahaya, maka intensitas cahaya yang di tunjukkan oleh lux meter semakin tinggi dengan keadaan suatu ruangan kamar dalam hasil pengujian ini marker bisa dideteksi kurang lebih mulai dari 2 lux sampai 200 lux diatas 200 lux marker sulit untuk di deteksi.

1) Uji Pencahayaan diatas $\geq 201$ Lux

Pada uji yang peratama yang dilakukan dengan pencahayaan lux diatas 200 lux dan marker tidak dapat di deteksi

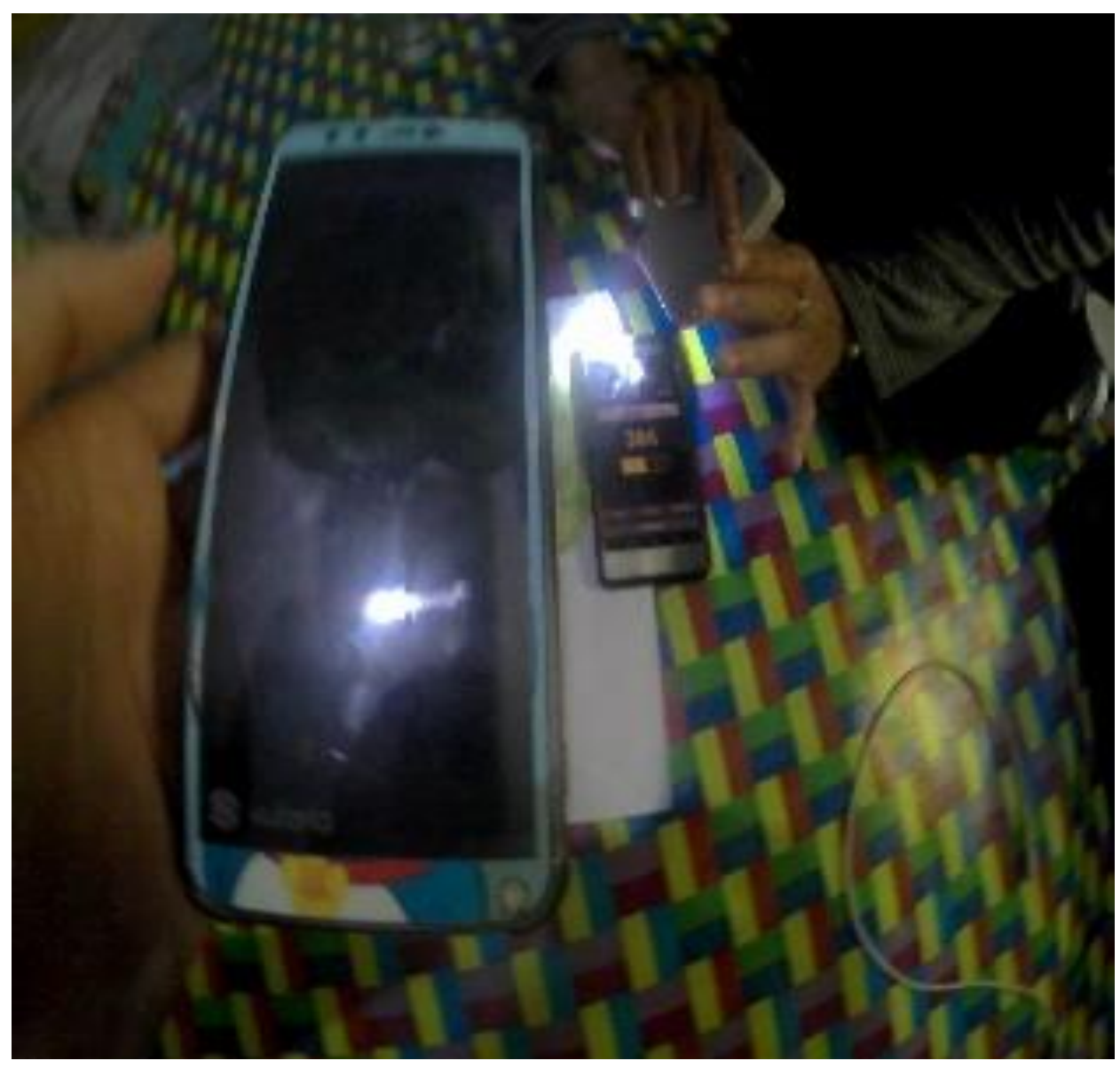

Gambar 5. 6. Tampilan dari Uji Pencahayaan Diatas 200 Lux

2) Uji Pencahayaan antara 7 Lux - 200 Lux 
Pada uji yang kedua ini dengan 7 lux sampai 200 lux marker masih bisa di deteksi dengan baik

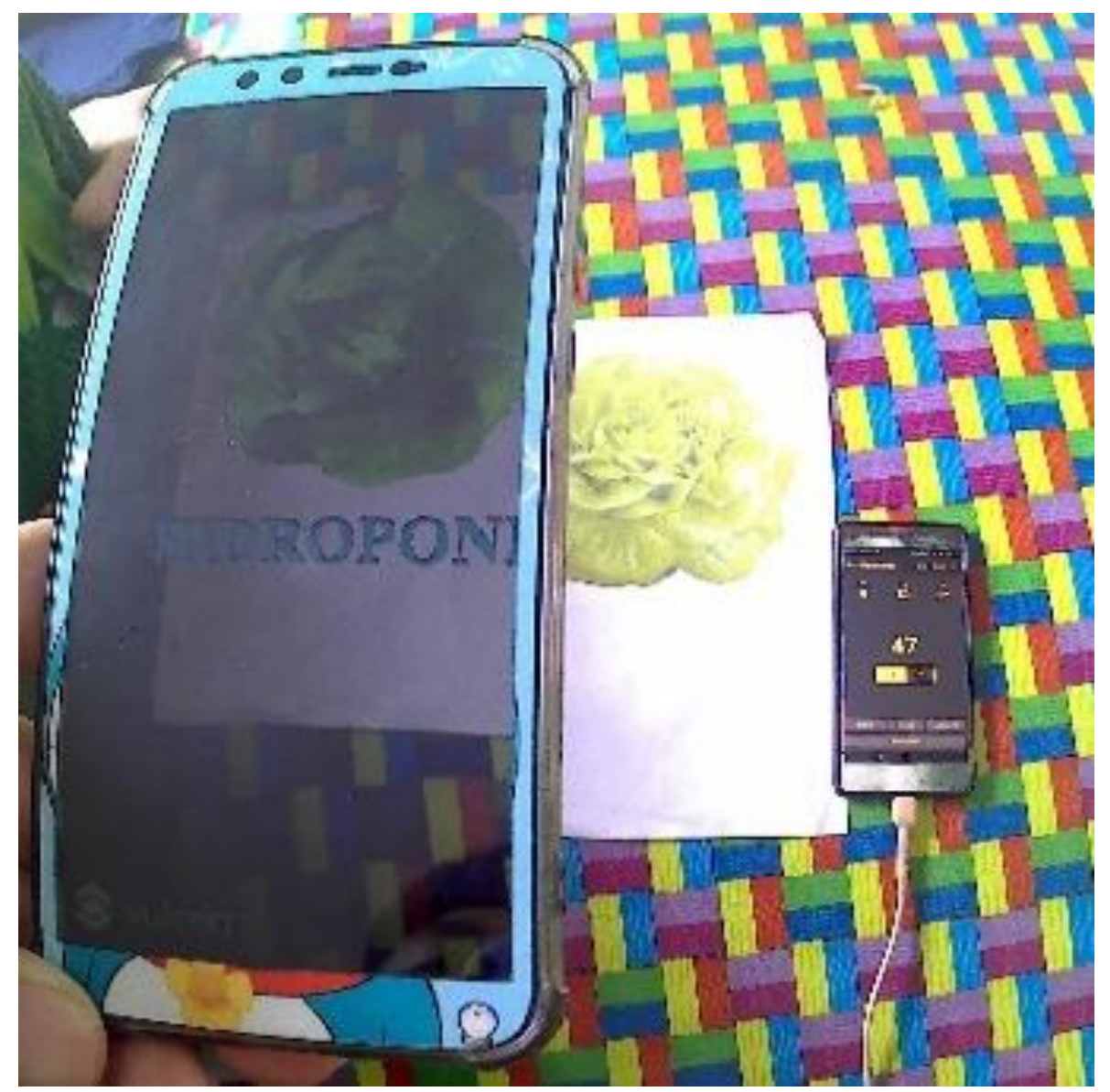

Gambar 5. 7. Tampilan dari Uji Pencahayaan 7 - 200 Lux

3) Uji Pencahayaan antara 2 Lux - 6 Lux

Pada uji pencahayaan ini dengan 2 sampai 6 lux marker masih bisa dideteksi namun tidak terlalu baik dalam mendeteksi marker. 


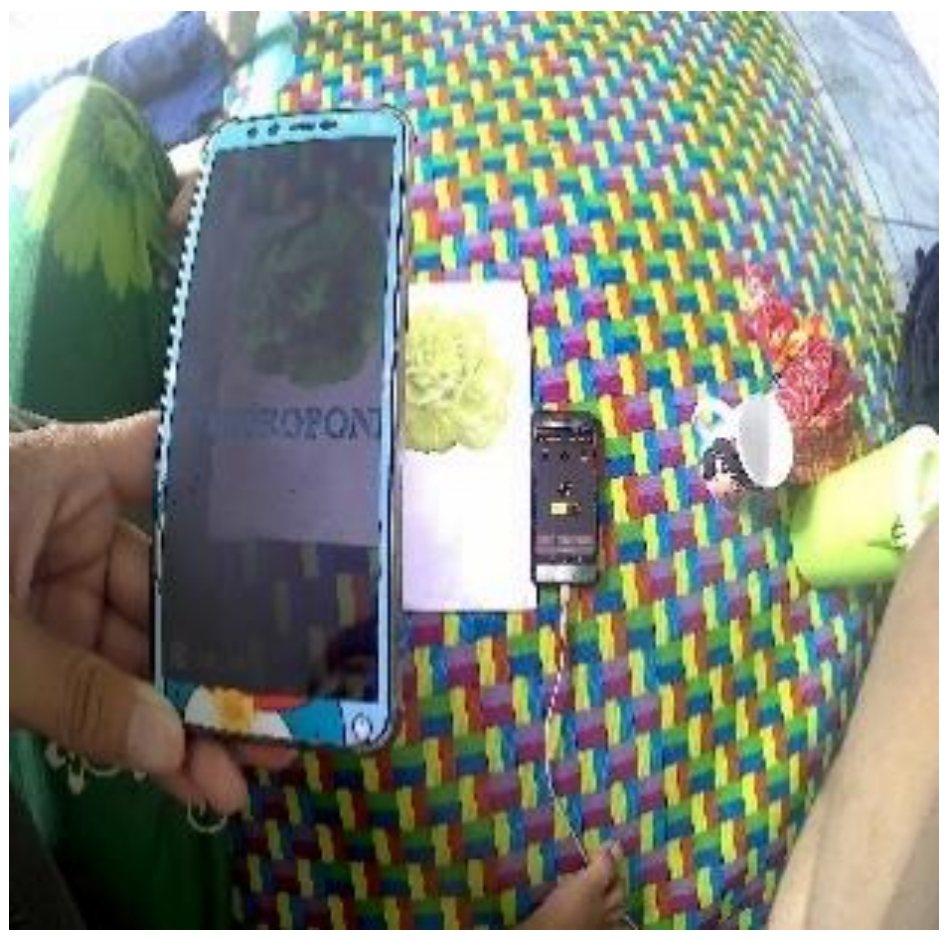

Gambar 5. 8. Tampilan dari Uji Pencahayaan antara 2 Lux - 6 Lux

4) Uji Pencahayaan dibawah $\leq 1$ Lux

Pada uji yang pencahayaan terakhir Dengan dibawah 1 lux marker tidak dapat dideteksi.

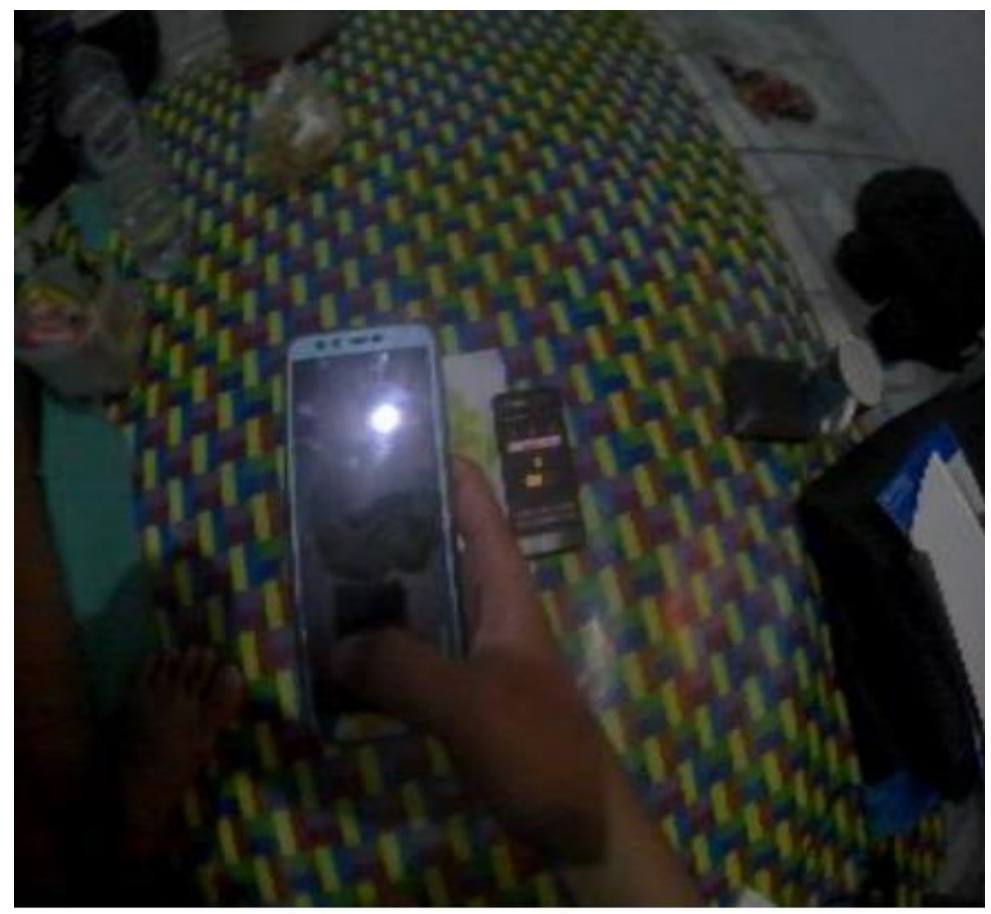

Gambar 5. 9. Tampilan dari Uji Pencahayaan Dibawah 1 Lux 


\section{b. Uji Jarak}

Selain pencahayaan Jarak juga menjadi masalah dalam pelacakan marker, ketika marker bergerak menjauhi kamera, maka marker akan terlihat kecil, dan mungkin tidak cukup detail untuk dapat dengan benar mengidentifikasi pola pada marker. Namun saat marker terlalu dekat dengan kamera maka akan sulit juga dalam pendektesian marker.

Hasil ini didapatkan dengan menggerakkan marker menjauhi kamera sampai pada jarak tertentu objek virtual 3 dimensi akan muncul atau terdekteksi dan sampai batas paling jauh marker terdekteksi. Seperti yang terlihat pada gambar berikut:

1) Marker Diuji dari Jarak $10 \mathrm{~cm}$

Pada uji ini marker dijauhkan dengan jarak $10 \mathrm{~cm}$ dalam hal ini marker dapat terdeteksi dengan baik dengan tampilan 3D yang tidak sempurna.

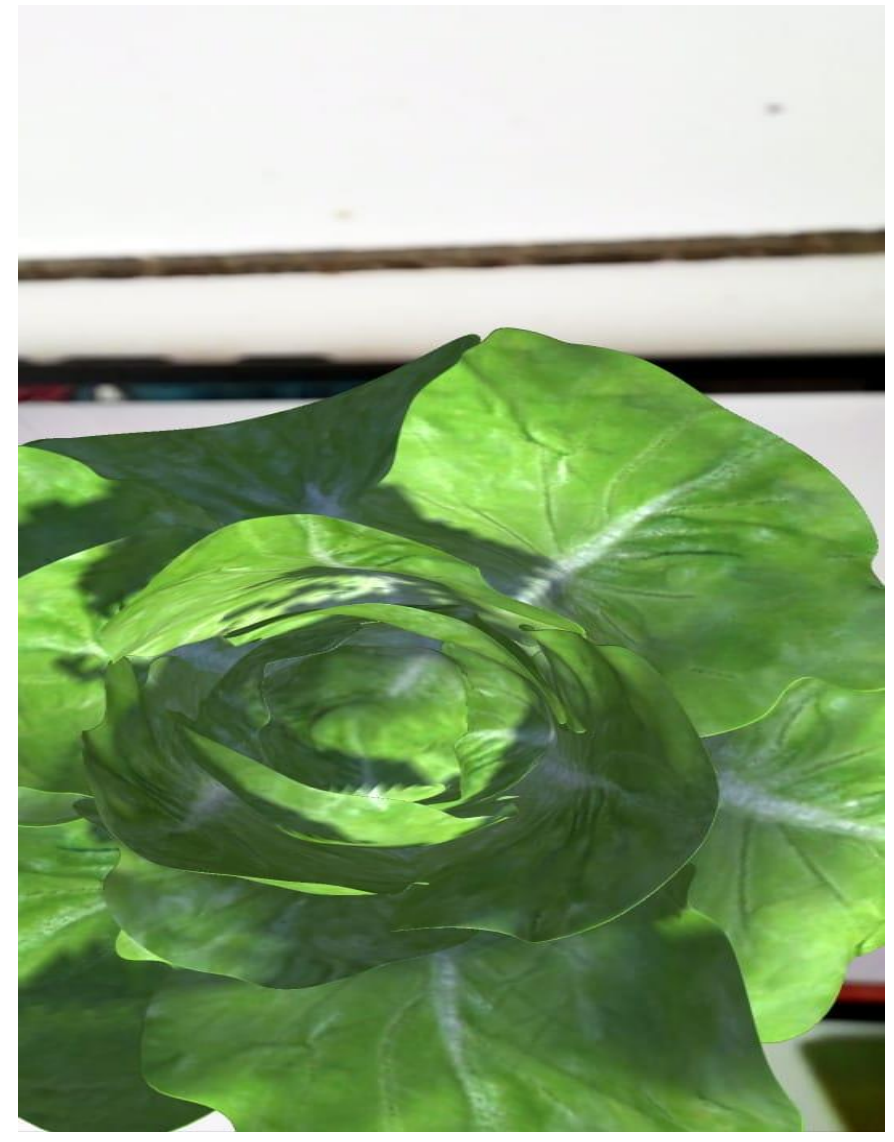

Gambar 5. 10. Tampilan Hasil Deteksi Marker Dari Jarak 10cm 
2) Marker Diuji dari Jarak $30 \mathrm{~cm}$

Peneliti mencoba menjauhkan marker sekitar $30 \mathrm{~cm}$ meter dan hasilnya marker dapat di deteksi dengan baik dengan tampilan 3D yang sempurna.

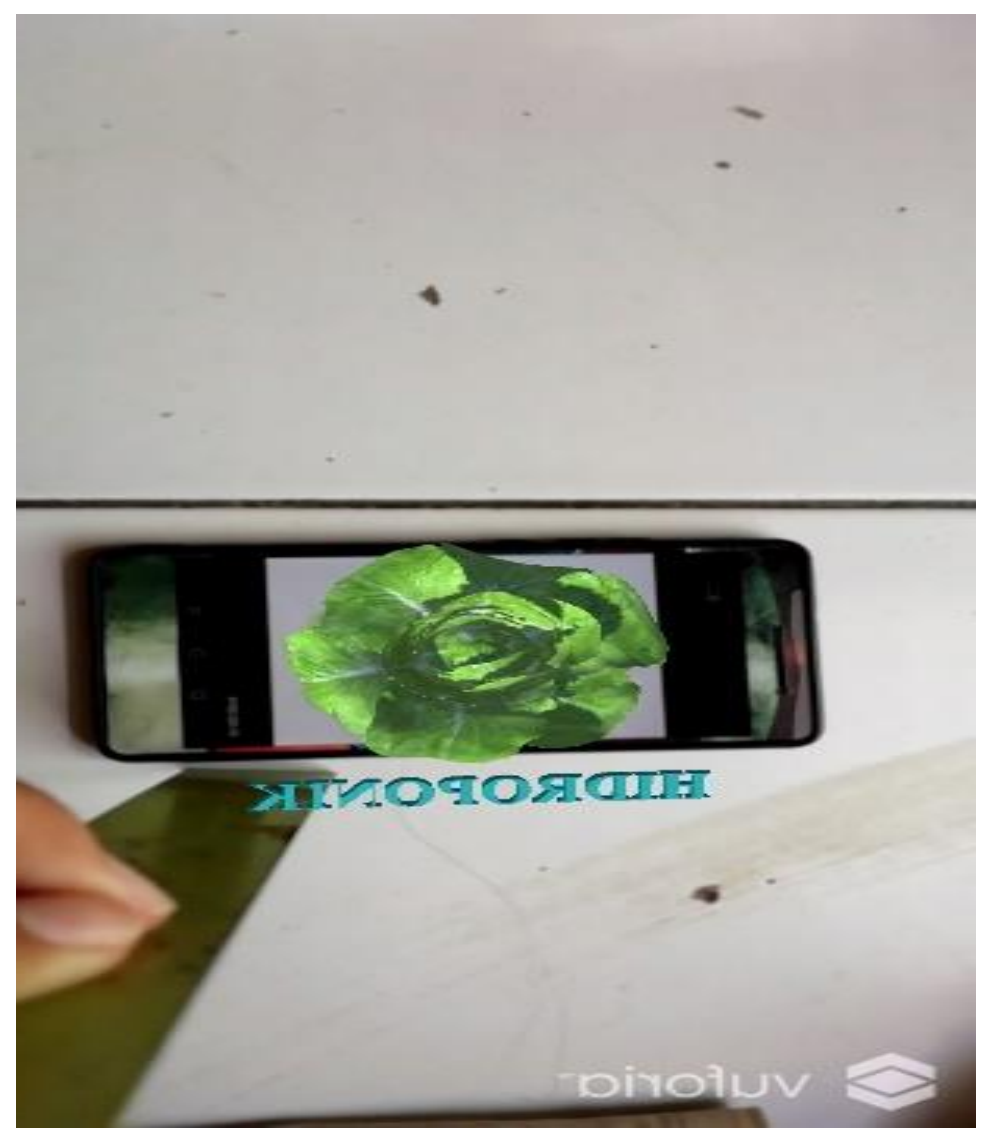

Gambar 5. 11.Tampilan Hasil Deteksi Marker dari Jarak $30 \mathrm{~cm}$

3) Marker Diuji dari Jarak $60 \mathrm{~cm}$

Selanjutnya uji jarak ditambah menjadi $60 \mathrm{~cm}$ hasilnya marker tetap dapat di deteksi dengan baik namun tampilan 3D semakin mengecil. 


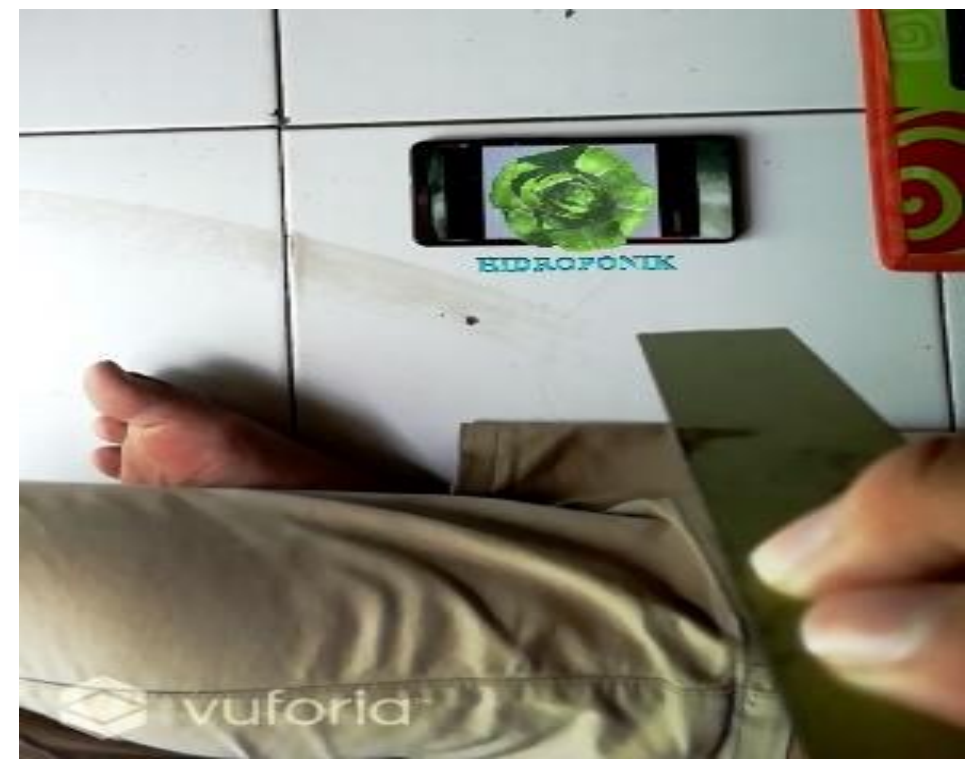

Gambar 5. 12.Tampilan Hasil Deteksi Marker dari $60 \mathrm{~cm}$

4) Marker Diuji dari Jarak $120 \mathrm{~cm}$

Peneliti mencoba menambah jarak menjadi $120 \mathrm{~cm}$ dan hasilnya dapat dideteksi namun dengan jarak diatas $120 \mathrm{~cm}$ marker sudah tidak dapat di deteksi.

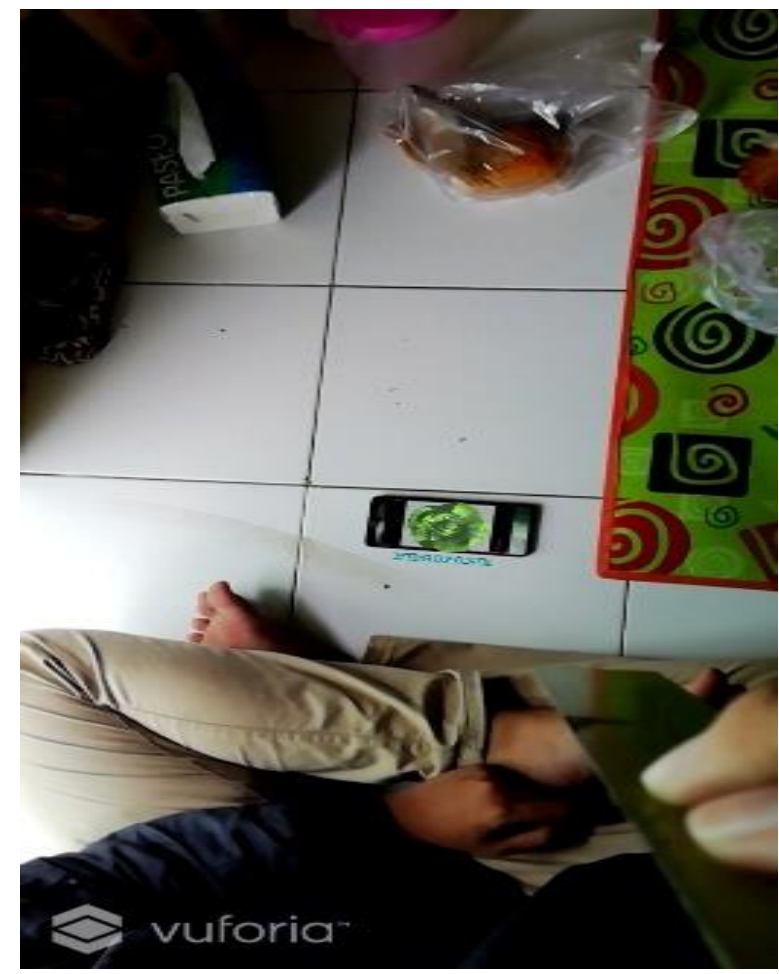

Gambar 5. 13.Tampilan Hasil Deteksi Marker dari $120 \mathrm{~cm}$ 


\section{c. Uji Daya Tahan Marker}

Pada tahap ini daya tahan marker dengan menggunakan kertas maka perlu pengujian dalam penteksian marker dengan mencoret, merobek, meremuk kertas dalam uji ini bisa diliat pada di gambar di bawah ini

1) Uji Marker dengan Dicoret-coret
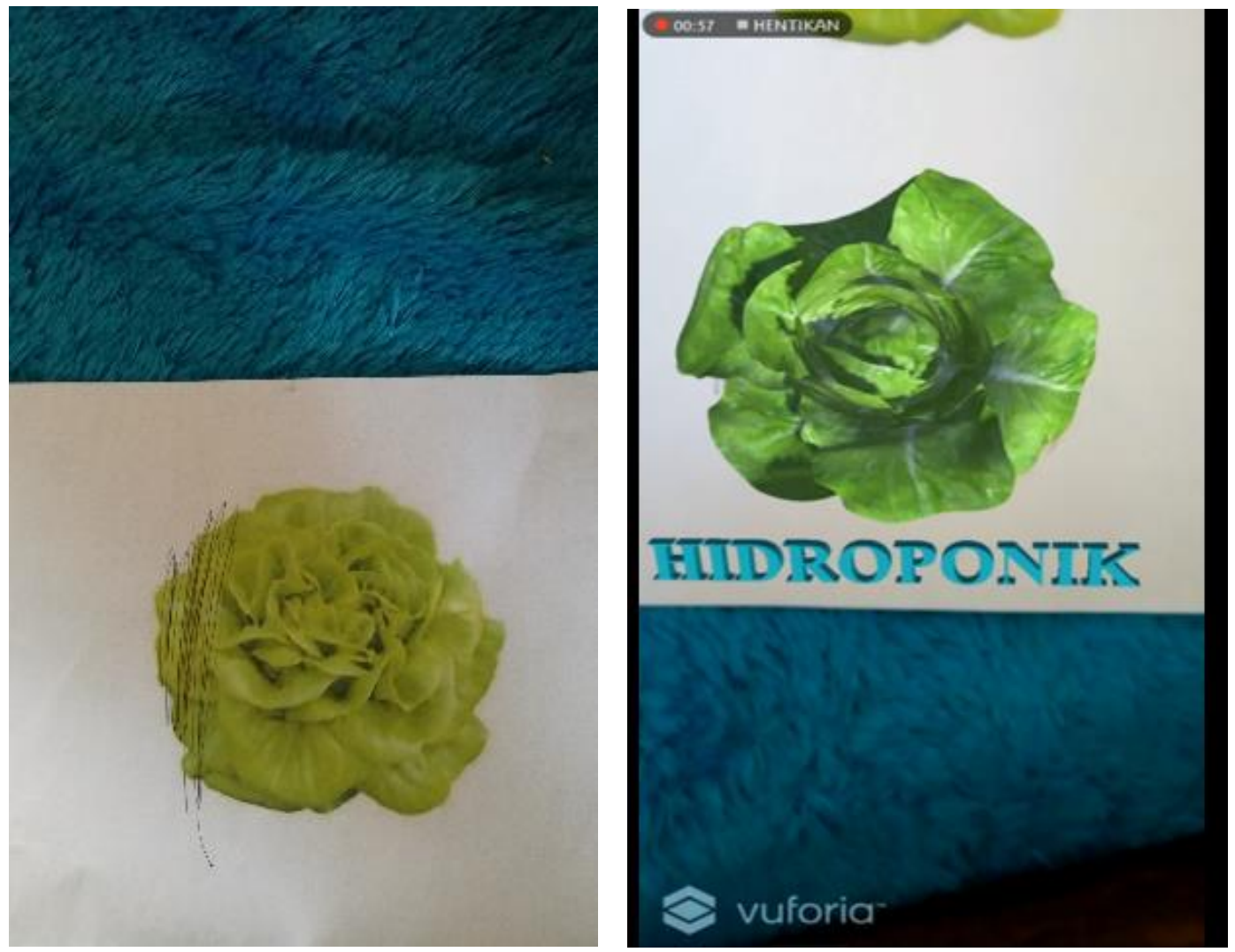

Gambar 5. 14. Uji Marker Dicoret (kiri) dan Marker Tetap Terdeteksi (kanan)

Pada uji ini marker dicoret hampir 1/4 dari bagian marker dan setengah bagian marker. Hasil daya tahan marker adalah (1) Pada uji yang pertama ini dengan marker di coret marker masih dapat terdeteksi; dan (2) Namun apabila dicoret sampai setengah bagian marker tidak dapat dideteksi. 
2) Uji Marker dengan Dirobek
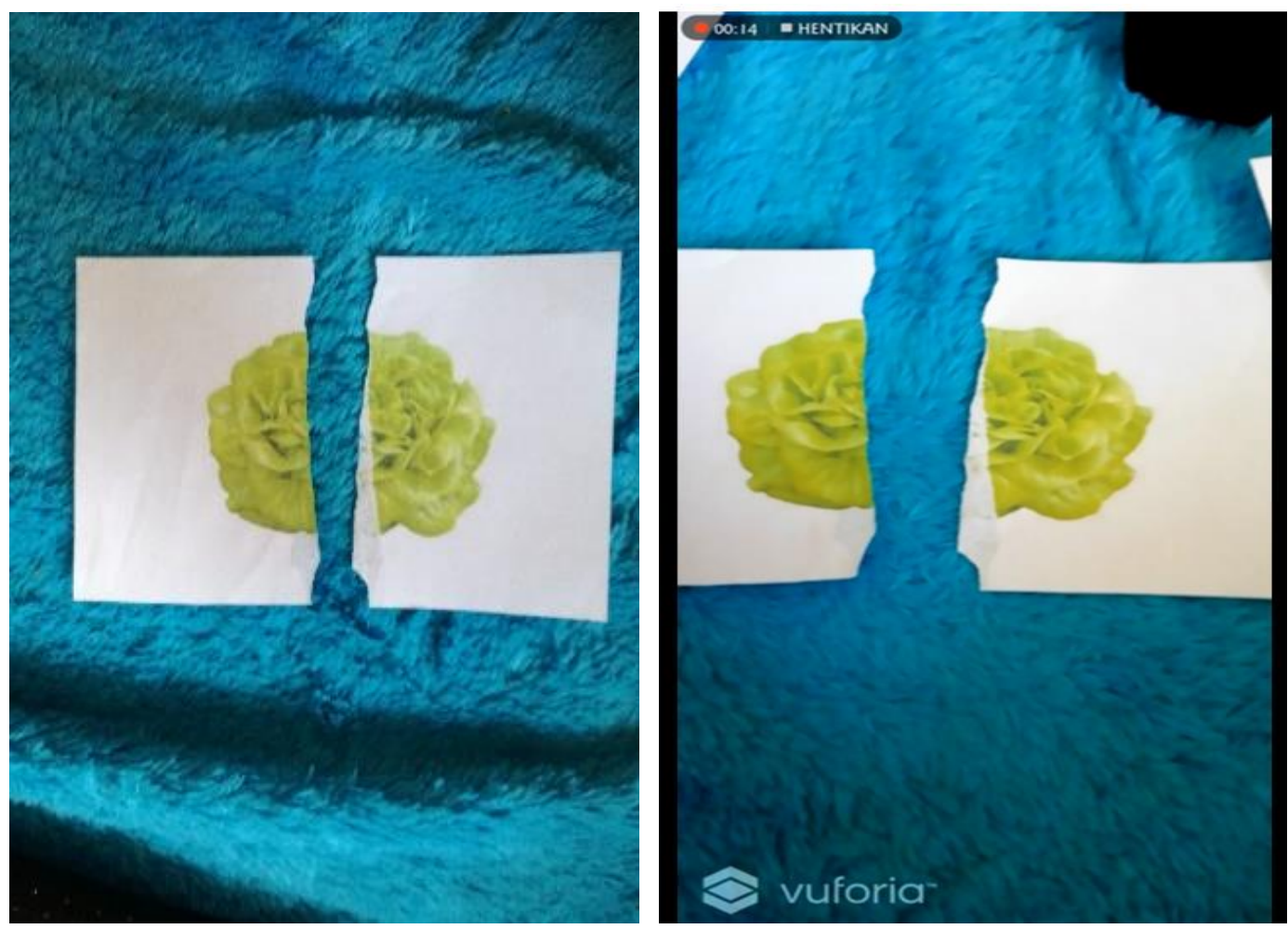

Gambar 5. 15. Uji Marker Dirobek (kiri) dan Marker Tidak Terdeteksi (kanan)

Saat uji marker mecoba dengan pengujian dengan cara di robek yang membuat marker terbelah menjadi dua. Hasil daya tahan marker adalah (1) Mencoba merobek marker dan hasil marker tidak dapat terdeteksi; dan (2) apabila marker direkatkan lagi sekitar $1 \mathrm{~cm}$ marker masih bisa terdeteksi. 
3) Uji Marker dengan Diremuk
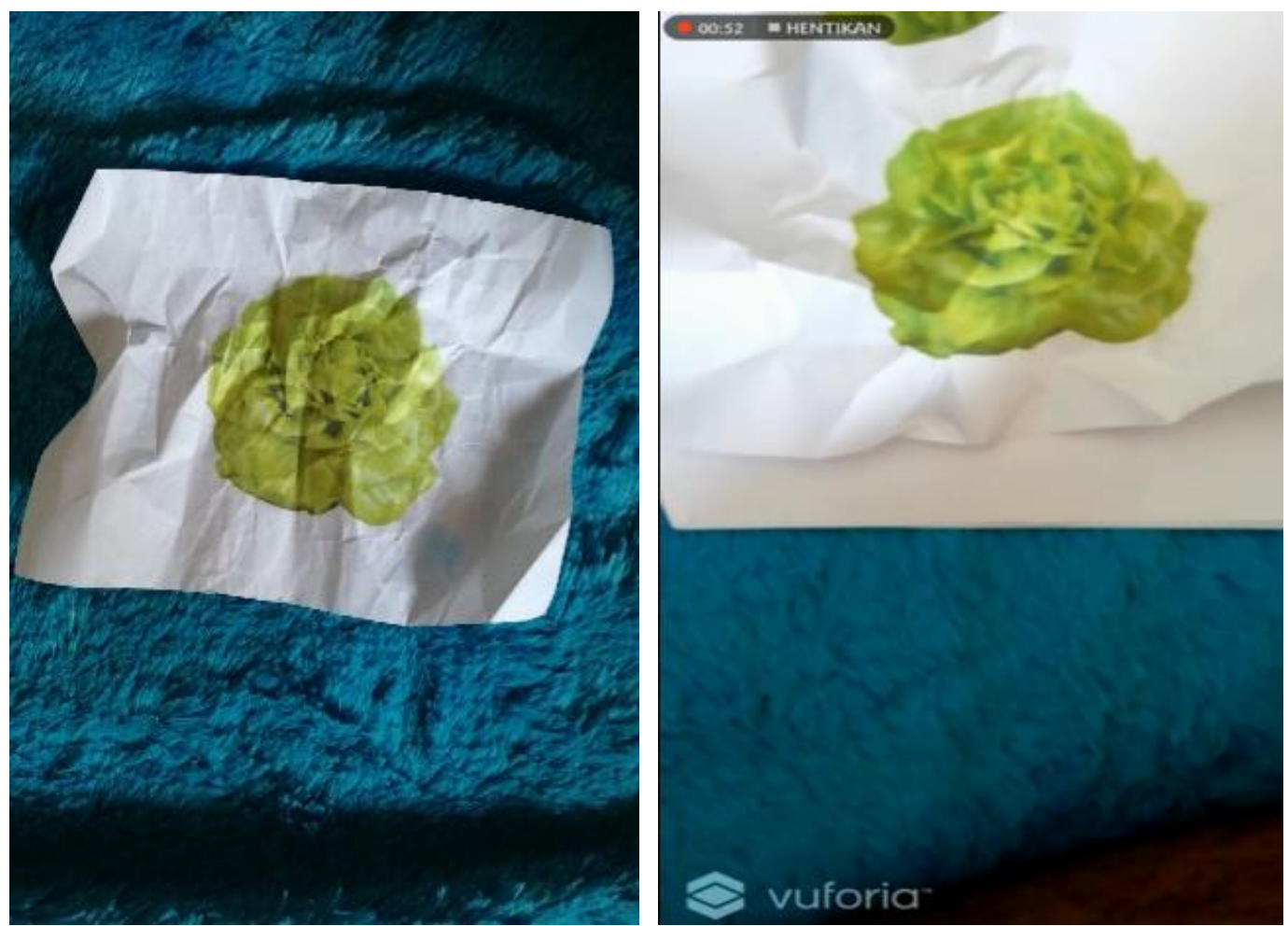

Gambar 5. 16. Uji Marker Diremuk (kiri) dan Marker Tidak Terdeteksi (kanan)

Saat uji marker mecoba dengan pengujian dengan cara diremuk yang membuat marker terlipat-lipat. Hasil daya tahan marker adalah (1) Uji dengan meremukan marker pada uji ini marker tidak dapat di deteksi; (2) Saat dirapikan kembali tetap tidak dapat terdeteksi.

\section{d. Uji dengan Beda Smartphone}

Dari hasil uji ini kualitas smartphone tidak terlalu berpengaruh dalam pendekteksian marker dri 4 smartphone yang di uji semuanya berhasil mendeteksi marker dengan baik.

1) Uji dengan Smartphone Merk Huawei P9 Lite

Spesifikasi handphone: Ram 3 GB, Camera 13 MP, Android Versi 7.0. Hasil pada uji ini menggunkaan handphone Huawei P9 Lite yaitu marker dapat terdeteksi dengan baik dan juga secara cepat mendeteksi marker. 


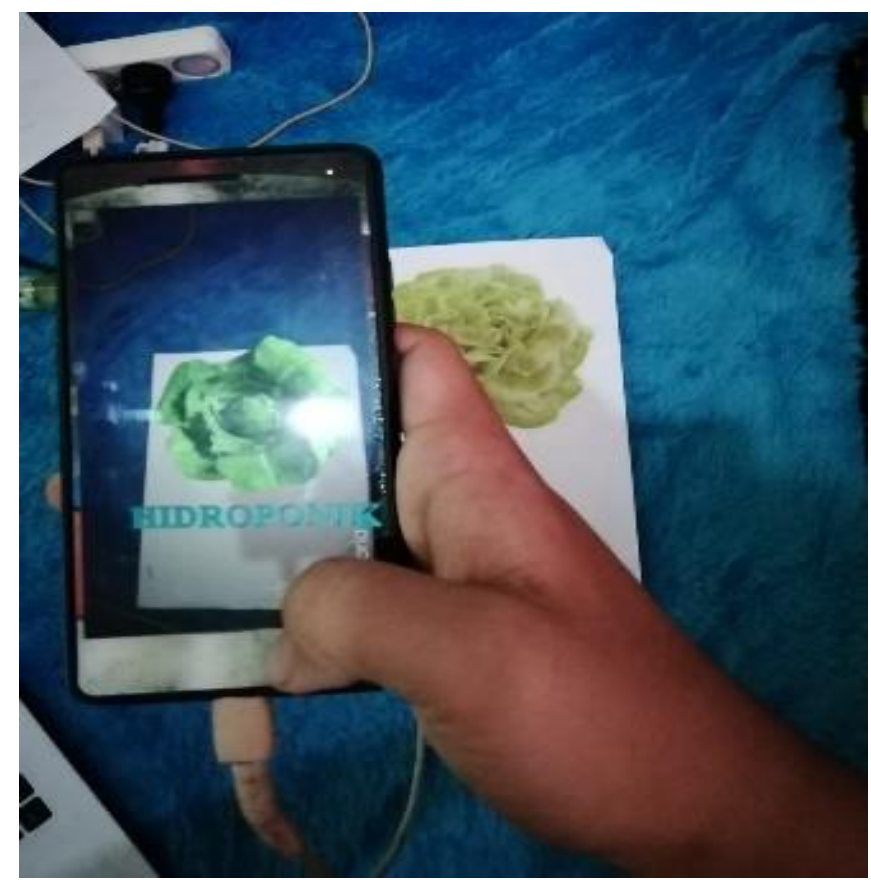

Gambar 5. 17. Uji Marker dengan Smartphone Huawei P9 Lite

2) Uji dengan Smartphone Merk Honor 9 Lite

Spesifikasi handphone: Ram 3 GB, Camera 16 MP, Android Versi 8.0. Hasil pada uji ini dengan handphone Honor 9 lite marker dapat terdeteksi dengan baik dan juga secara cepat mendeteksi marker.

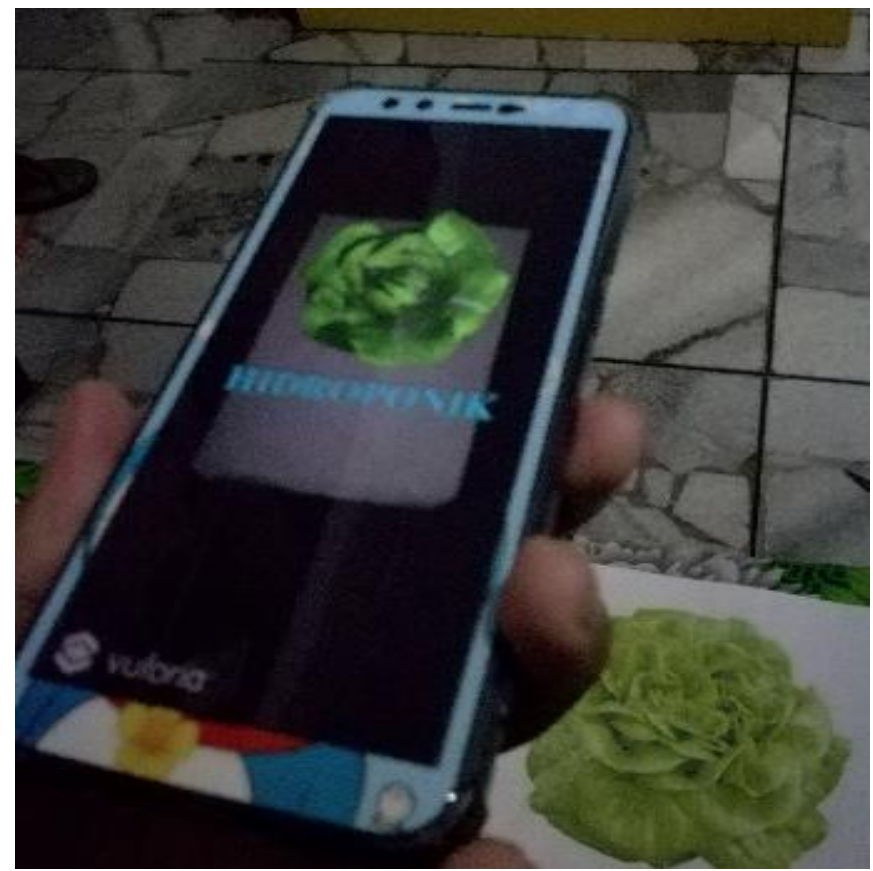

Gambar 5. 18.Uji Marker dengan Smartphone Honor 9 Lite 
3) Uji dengan Smartphone Merk Xiomi Redmi Note $4 X$

Spesifikasi handphone: Ram 3 GB, Camera 13 MP, Android Versi 7.0. Pada uji ini Dengan handphone Xiomi Redmi Note 4X marker dapat terdeteksi dengan baik dan secara cepat mendeteksi marker.

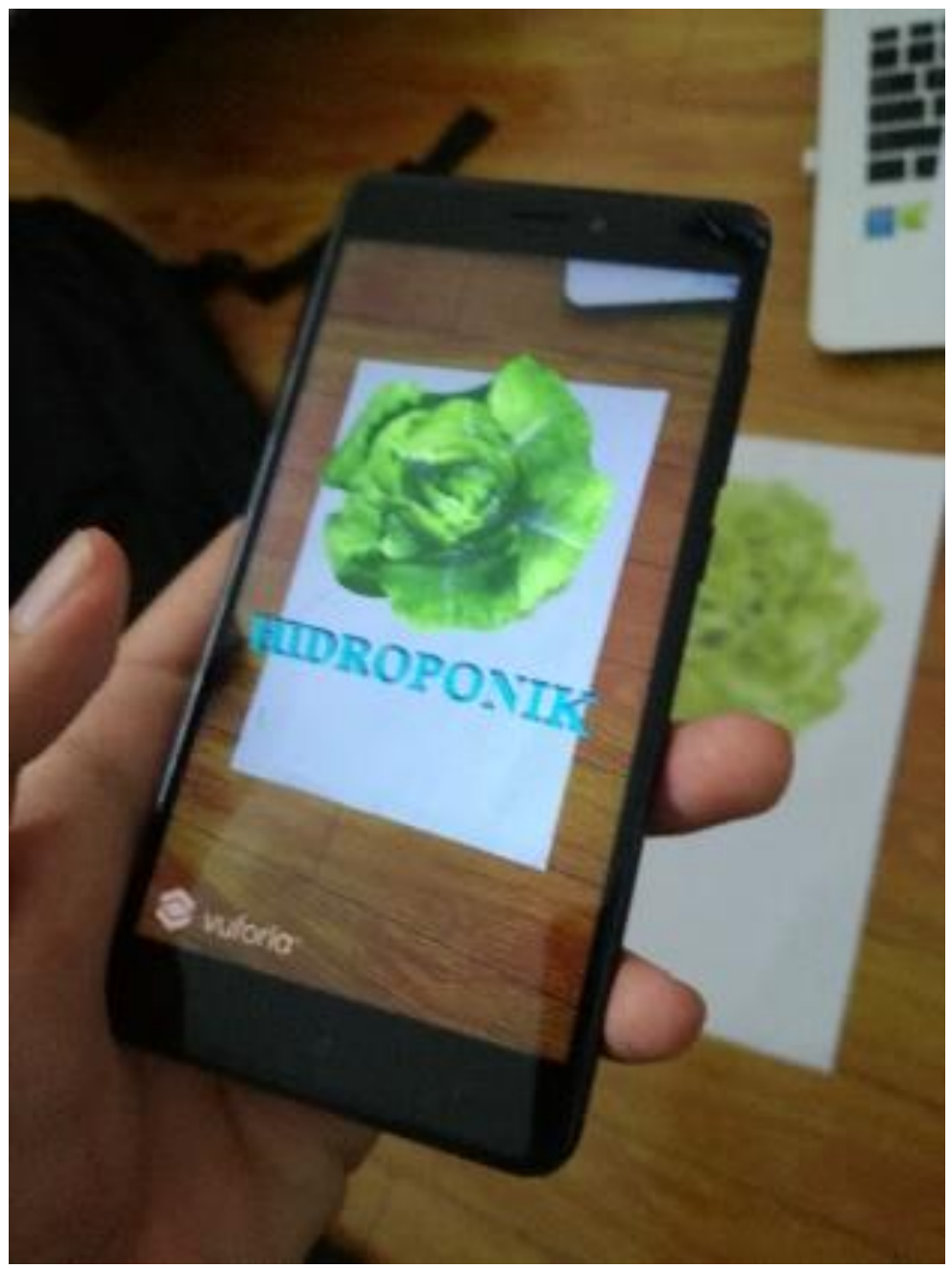

Gambar 5. 19. Uji Marker dengan Smartphone Xiomi Redmi Note 4X

4) Uji dengan Smartphone Xiomi $5 \mathrm{~A}$

Spesifikasi handphone: Ram 2 GB, Camera 13 MP, Android Versi 7.0. Pada uji ini dengan xiomi 5A lite marker dapat terdeteksi dengan baik dan Xiomi 5a dengan ram $2 \mathrm{gb}$ marker tetap terdeteksi dengan cepat. 


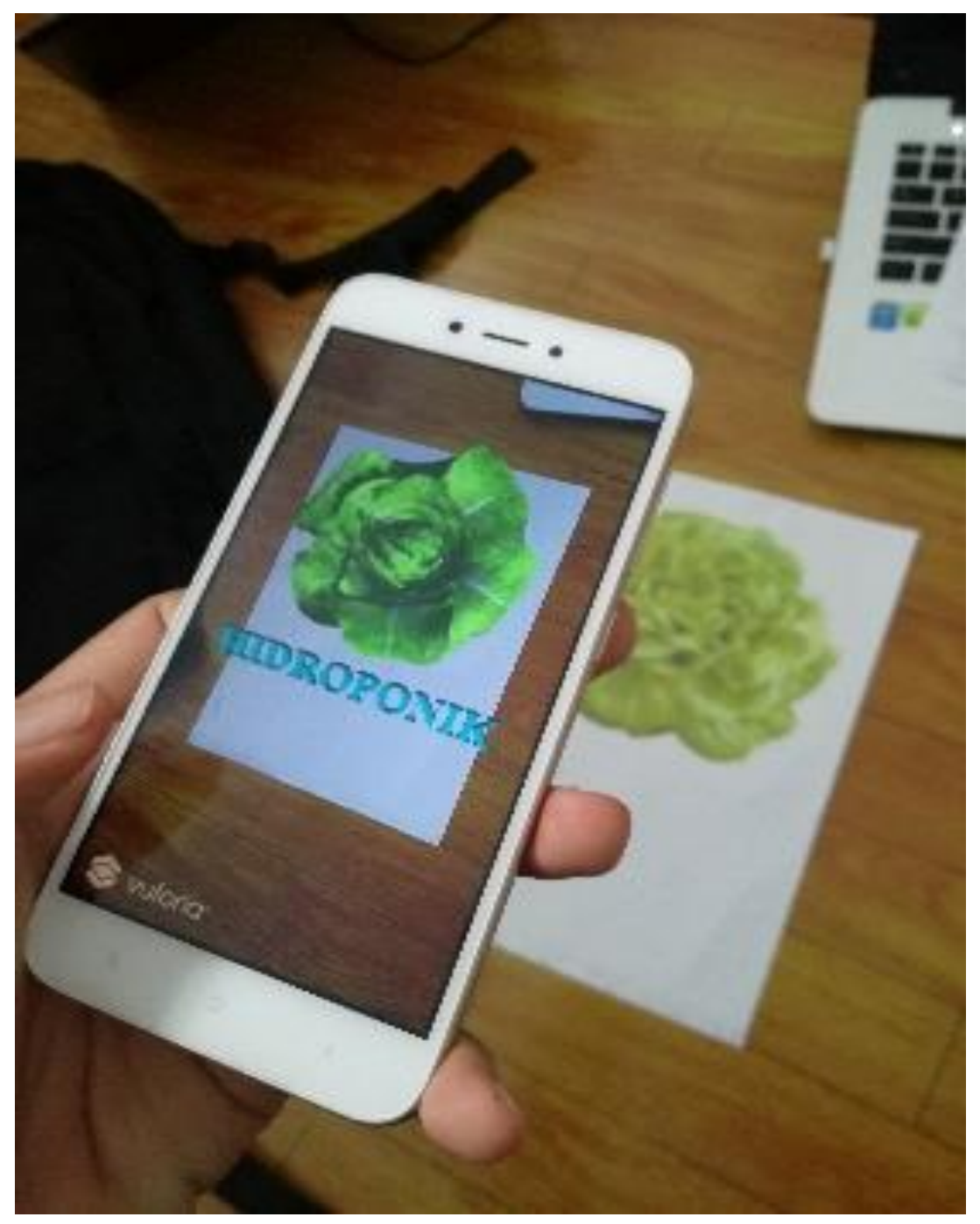

Gambar 5. 20. Uji Marker dengan Smartphone Xiomi 5A 


\section{RENCANA PENELITIAN BERIKUTNYA}

Pada penulisan ilmiah ini, penulis menganalisis implementasi Augmented Realitity untuk media pembelajaran hidroponik, pada penelitian berikutnya penulis berencana ingin membuat aplikasi pembelajaran hidroponik sesuai alur menanam hidroponik menggunakan Augmented Reality yang didalamnya terdapat informasi, penjelasanya menggunakan audio dan gambar 3D maupun animasi. Kemudian aplikasi ini dapat diakses menggunakan smartphone.

Dengan adanya aplikasi ini yang menggunakan Augmented Reality, ini dapat memudahkan dalam mempelajari maupun memahami cara menanam hidroponik tanpa harus datang ke tempat penanaman hidroponik.

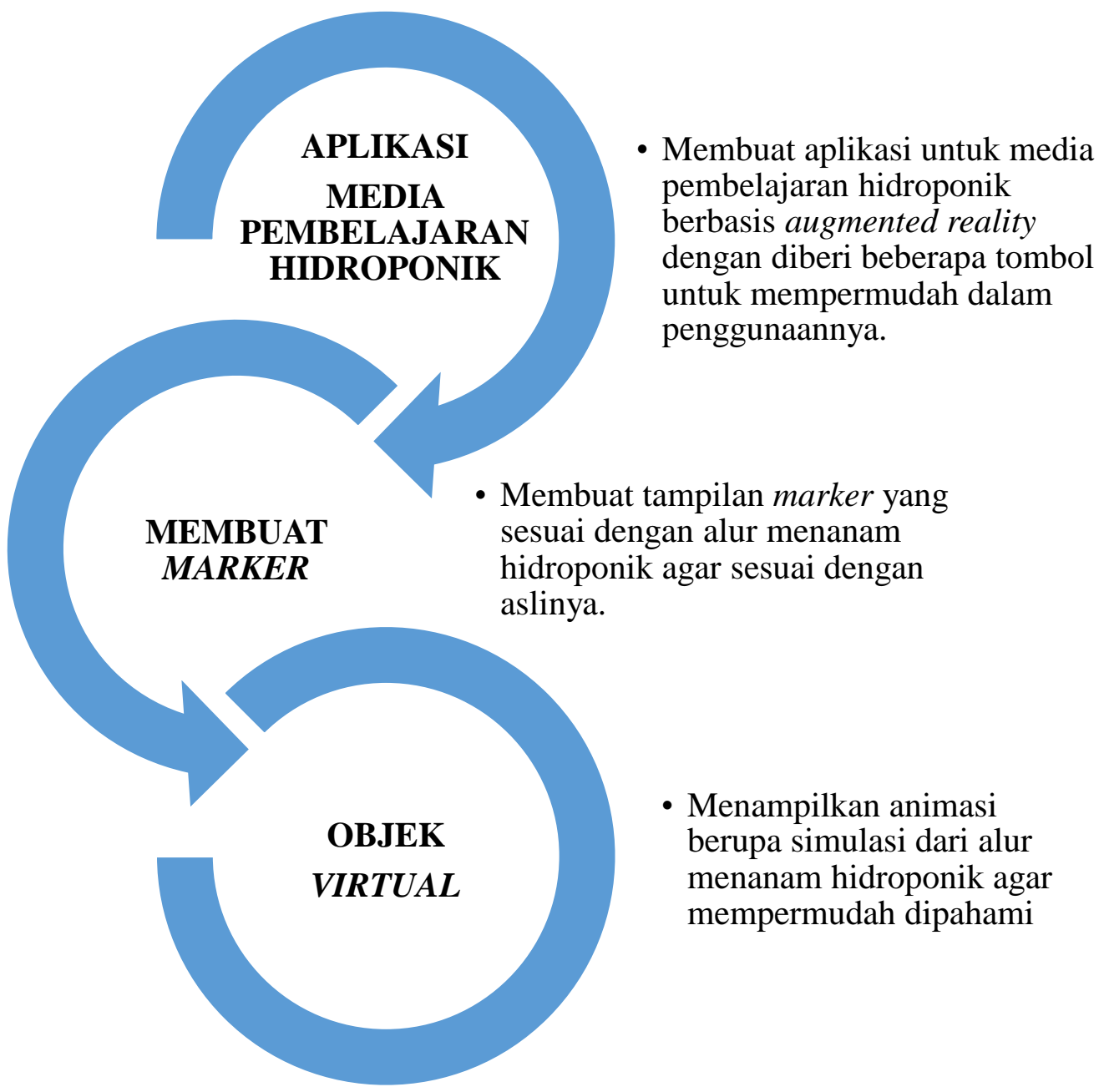

Gambar 6. 1. Kerangka Pemikiran Penelitian Selanjutnya 


\section{KESIMPULAN DAN SARAN}

\subsection{Kesimpulan}

Berdasarkan hasil penelitian dan pembahasan pada penulisan ilmiah ini, maka kesimpulan yang dapat diambil adalah sebagai berikut:

a. Pada hasil penelitian yang dilakukan jarak maupun pencahayaan adalah faktor yang paling mempengaruhi pendekteksian marker.

b. Dengan Augmented Reality tampilan media pembelajaran menjadi lebih menarik dan mudah dipahami.

c. Penggunaan kertas sebagai media marker membuat marker rentan rusak atau tidak dapat terdeteksi.

\subsection{Saran}

Berdasarkan hasil dari penelitian ini, beberapa saran untuk kedepannya:

a. Dalam membuat marker, baiknya menggunakan marker dengan kualitas gambar dan pencahayaan yang baik untuk membantu dalam deteksi marker.

b. Dalam penggunaan kertas sebagai media marker baiknya menggunakan kertas yang tidak mudah rusak dan luntur.

c. Menambahkan animasi dan audio untuk mempermudah dalam memahami pembelajaran. 


\section{DAFTAR PUSTAKA}

Alfi, S., Meyti, E., \& Sandi, P. (2016). Analisis dan Implementasi Metode MarkerBased Tracking pada Augmented Reality Pembelajaran buah-buahan. jurnal ilmiah komputer dan informatika (komputa).

Andriyadi, \& Anggi. (2011). Augmented Reality with ARToolkit Reality Leaves a lot to imgine. Penerbit ARTeam \& Nulis buku.com.

Arikunto. (2010). Prosedur Penelitian : Suatu Pendekatan Praktek . Rineka Cipta : Jakarta .

Arsyad, A. (2002). Media Pembelajaran. Raja Grafindo.

Brian, Y. (2012). Teknologi Augmented Reality Untuk Buku Pembelajaran Hewan Pada anak Usia DIni Secara Virtual. yogyakarta : STIMIK AMIKOM.

Candra, A., Rachmawati, D., \& Budiman, M. (2014). Perancangan Mobile Augmented Reality Sytem untuk Wisata Sejarah. SENARAI.

Chari, S., \& Narayana, P. (2008). Augmented Reality Using Over-Segmentation. Center for Visual Information Tecnology. international institute of information technology.

Christoper. (2012). Markerlees Augmented Reality For Panoramic Sequences. school of informaation technology and Engineerning Faculty of engineering Universit Of Ottawa Canada.

Dedy, A. (2017). Implementasi Augmented Realty untuk Pembelajaran Interaktif. Ilkom Jurnal Ilmiah volum 9 nomer 2.

Djuniarto. (2013). Augmented Reality Menggunakan Library ARtoolkit dengan Marker Biner. ejurnal stikom bayuwangi.

Erlangga, E. and Dharmawan, Y.Y., 2017. Implemantasi Apps Teacher Kit untuk Proses Administrasi Dosen Mandiri yang Efektif, Efisien, dan Paperless. 
Explore: Jurnal Sistem Informasi dan Telematika (Telekomunikasi, Multimedia dan Informatika), 8(2).

Fernando, M. (2013). Membuat Aplikasi Android Augmented Reality menggunakan Vuforia SDK dan UNITY. MANADO : INFORMATIKA.

Guntur, S. (2004). Implementasi Dalam Birokrasi Pembangunan. Bandung : Remaja Rosdakarya Offset, 39.

Ibadarrohman, Nur , S. S., \& Anacotiana, k. (2018). Sistem Kontrol Dan Monitoring Hidroponik Barbasis Android. konferensi Nasional Sistem Informasi.

Ilias, A., Razak, M. Z. A., Rahman, R. A., Yasoa', M. R., (2009). Journal of Computer and Information Science : End-User Computing Satisfaction (EUCS) in Computerised Accounting System (CAS): Which the Critical Factors? A Case in Malaysia,: 18-24

Indriani, R., \& Sugiato, B. (2016). Pembuatan Augmented Reality tentang pengenalan hewan untuk usai dini berbasis Android menggunakan metode image tracking vuforia. yogyakarta : STIMIK AMIKOM.

Julia, S., Popy, M., \& Sitti, N. A. (2018). Implementasi Augmented Realty Sebagai Pembelajaran Pertumbuhan Tanaman Dikotil dan Monokotil untuk Sekolah Dasar. Jurnal sistem informasi ,teknologi informatika dan komputer.

Kustandi, \& Sutjipto. (2013). Media Pembelajaran Manual dan Digital. Bogor: Ghalia Indonesia.

Lia, K. (2015). Perkembangan Teknologi Augmented Realty Sebagai Media Pembelajaran Interaktif pada Mata Kuliah Kimia Dasar. Volum XI no.1 ISSN 1979-8911.

Lingga, P. (1984). Hidroponik Bercoccok tanam tanpa media tanah. jakarta : penebar swadaya.

Nursyanti, R., \& Erlangga, E. (2013, August). The Evaluation of Information System Performance in Higher Education Case Study with EUCS Model at 
Bandar Lampung University. In International Conference on Engineering and Technology Development (ICETD).

Pertanian, P. d. (2017). Buletin Konsumsi Pangan. Pusat data dan informasi pertanian - kementrian pertanian, volume 8 nomer 1 .

Pratama, M. (2014). Penerapan Augmented Reality pada Perancangan Aplikasi Pengenalan Alat Musik Taganing Batak Berbasis Android. Universitas Sumatra Utara : Medan.

Prof. Dr. Suryana, M.SI. (2010). Metodologi Penelitian Model Praktis Penelitian Kuantitatif dan Kualitatif. Universitas Pendidikan Indonesia.

Purbajanti dkk. (2017). Hydroponic Bertanam Tanpa Tanah. digimedia,semarang.

Rahmat, B. (2011). Analisis dan Perancangan Sistem Pengenalan Bangun Ruang Menggunakn Augmented Reality . Universitas Sumatra Utara : Medan.

Roedavan, R. (2014). Unity Tutorial Game Engine. INFORMATIKA : Bandung.

Roidah, I. (2014). Pemanfaatan Lahan dengan Menggunakn Sistem Hidroponik. Jurnal Universitas Tulungagung Bonorowo.

Sanaky, A. (2013). Media Pembelajaran Interaktif - Inovatif . Yogyakarta:Kaukuba Dipantara.

Sastro, Y., \& Rokhmah, N. (2016). Hidroponik sayuran di perkotaan. seri pertanian perkotaan,BPTP DKI Jakarta ,Kementrian Pertanian.

Suprihatiningrum, J. (2013). Strategi Pembelajaran Teori Dan Aplikasi . Yogyakarta : AR - RUZZ media.

Susilana, R., \& Riyana, C. (2008). Media Pembelajaran. bandung : CV Wacana Prima, 1.

Tallei, \& dkk. (2017). Hidroponik untuk pemula. lembaga penelitian dan pengabdian kepda masyarakat, universitas sam ratulangi, ISBN : 978-60260359-2-9. 
Yulianto, N. (2012). Pembuatan Game 3 Dimensi Lost IN the Jungle dengan Menggunakan Unity 3D Game Engine. Yogyakarta : Sekolah Tinggi Manajemen Informatika dan K omputer AMIKOM. 


\section{LAMPIRAN}

Lampiran 1. Jadwal Kegiatan Bimbingan Penulisan Ilmiah

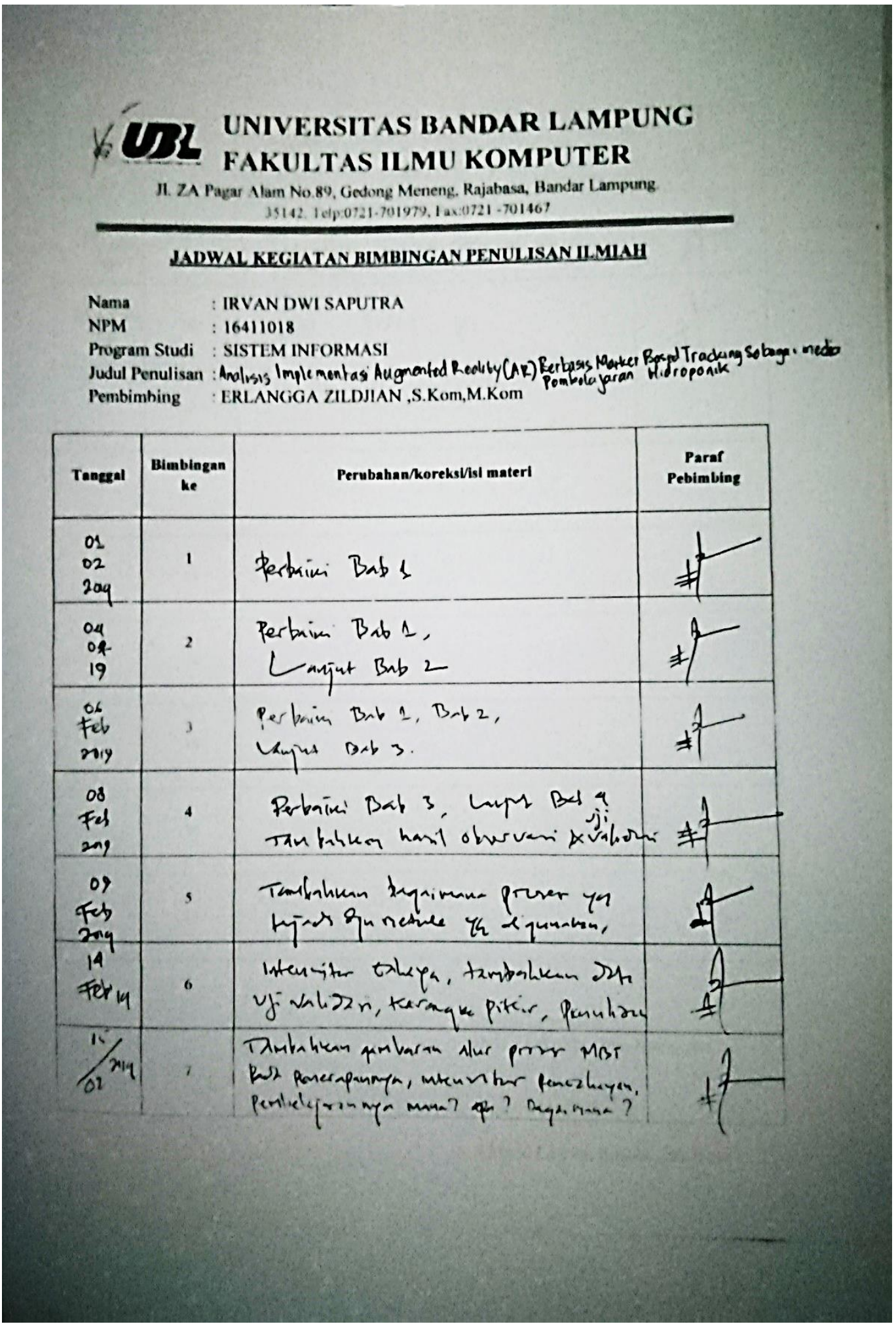




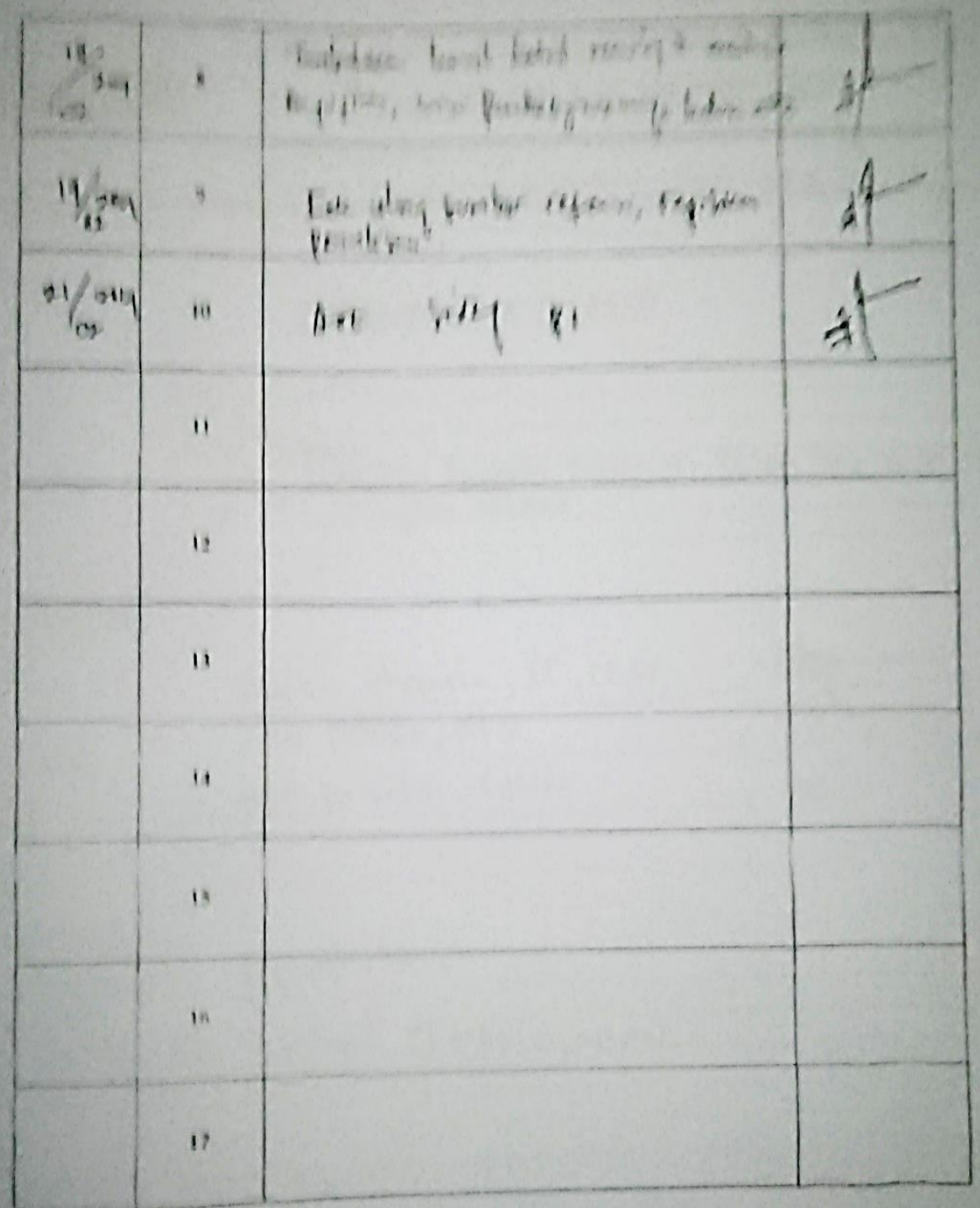

Ilandar I ampung.

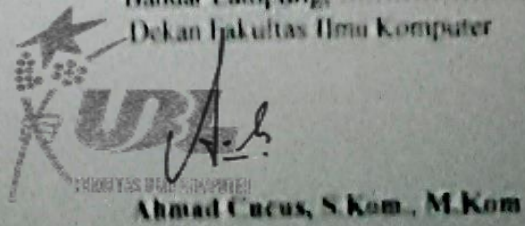




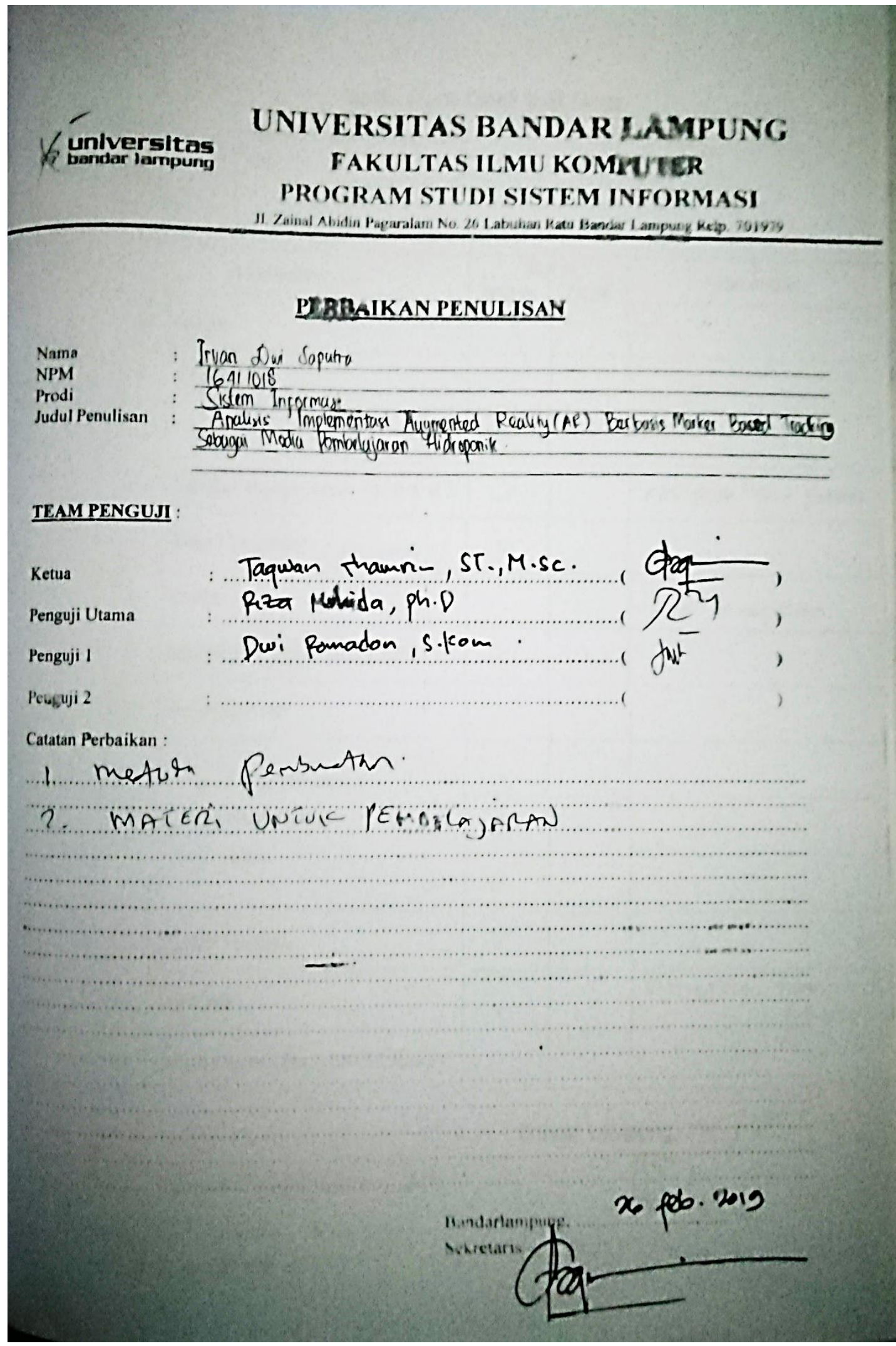


Lampiran 3. Berita Acara Cetak Soft Cover

\section{Berita Acara Cetak Sof Cower}

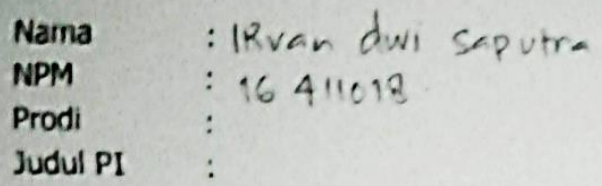

\begin{tabular}{|c|c|c|c|c|}
\hline \multirow{2}{*}{\multicolumn{2}{|c|}{ Kesesualan IsI }} & \multicolumn{2}{|c|}{ Status } & \multirow{2}{*}{ Keterangan } \\
\hline & & Sesuai & Tidax & \\
\hline 1. & Cover & & & \\
\hline 2. & Cover1 & $\checkmark$ & & \\
\hline 3. & Cover 2 & $\checkmark$ & & \\
\hline 4. & Lembar Pengesahan Form $1 \forall 2$ & $\checkmark$ & & AfG preaiken foner \\
\hline 5. & Kata Pengantar, asstraK & $\checkmark$ & & \\
\hline 6. & Daftar Isik & & $\checkmark$ & aga persaiticem \\
\hline 7. & Daftar (Tabel,Gambar,Grafik) & $\checkmark$ & & \\
\hline 8. & Isi Penulisan & & & \\
\hline \multirow{3}{*}{9.} & \multirow{3}{*}{$\begin{array}{l}\text { a. Judul Penulisan } \\
\text { b. Penomoran } \\
\text { c. Spasi }\end{array}$} & 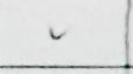 & & \\
\hline & & $\checkmark$ & & \\
\hline & & $v$ & & \\
\hline 10. & Daftar Pustaka & $\checkmark$ & & \\
\hline 11. & Lampiran & $\checkmark$ & & 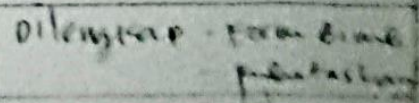 \\
\hline 12. & Sudut Cover (Nama,NPM,Judul') & & & 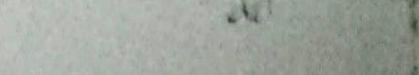 \\
\hline lea & 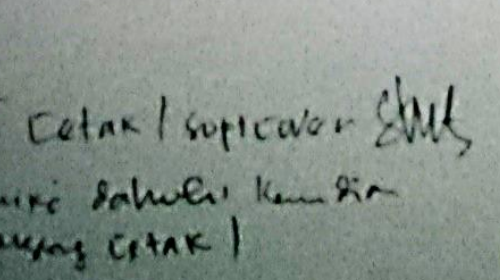 & \multicolumn{3}{|c|}{ Bandar Lampung, $25 / \mathrm{s}^{20 i n}$} \\
\hline
\end{tabular}

